\title{
Flood timescales: Understanding the interplay of climate and catchment processes through comparative hydrology
}

\author{
Ladislav Gaál, ${ }^{1}$ Ján Szolgay, ${ }^{1}$ Silvia Kohnová, ${ }^{1}$ Juraj Parajka, ${ }^{2}$ Ralf Merz, ${ }^{3}$ \\ Alberto Viglione, ${ }^{2}$ and Günter Blöschl ${ }^{2}$ \\ Received 13 October 2011; revised 29 February 2012; accepted 1 March 2012; published 12 April 2012.
}

[1] We analyze the controls on flood duration based on the concept of comparative hydrology. Rather than modeling a single catchment in detail, we compare catchments with contrasting characteristics in order to understand the controls in a holistic way. We analyze the hydrographs of 9223 maximum annual flood events in 396 Austrian catchments ranging from 5 to $\sim 10,000 \mathrm{~km}^{2}$ as a function of climatic controls such as storm type (synoptic and convective storms, rain-on-snow, snowmelt), and catchment controls such as soils, soil moisture, geology, and land form. The ratio of the flood volume and the flood peak is used as a measure of the flood duration or flood timescale. The results indicate that, spatially, the median flood timescales range from $16 \mathrm{~h}$ in the hilly catchments, where convective storms prevail, to $104 \mathrm{~h}$ in the lowland catchments where substantial inundation into the floodplain occurs. The range is even larger for different flood types, from $7 \mathrm{~h}$ for flash floods in the hilly catchments to $200 \mathrm{~h}$ for snowmelt floods in an Alpine area with deeply weathered rocks and deep soils. The results also indicate that the catchment area is not the most important control on the flood timescales. For the range of catchments considered here, climate is very important through storm type and antecedent soil moisture, and geology is very important through soil characteristics. The concept of comparative hydrology is also used to interpret the interplay of the processes controlling the flood duration at timescales from hours to millennia. It is argued that the flood timescale is a rich fingerprint of the hydrological processes in a catchment because it integrates a range of climate and catchment characteristics by a time parameter.

Citation: Gaál, L., J. Szolgay, S. Kohnová, J. Parajka, R. Merz, A. Viglione, and G. Blöschl (2012), Flood timescales: Understanding the interplay of climate and catchment processes through comparative hydrology, Water Resour. Res., 48, W04511, doi:10.1029/ 2011WR011509.

\section{Introduction}

[2] Understanding the duration of floods is important from both practical and theoretical perspectives. The duration of a flood is closely related to its volume, which is needed for numerous engineering purposes including the design of spillways and retention basins and the geotechnics of dams. Also, for a given runoff volume, flood duration and peak flow are inversely related so, if a design flood is estimated from rainfall its duration is a key parameter in the derivation. The duration of floods is also important for freshwater ecology and stream morphology [e.g., Klimešová, 1994; Karcz, 1972], and it may affect the magnitude of flood damage [Thieken et al., 2005; Apel et al., 2006]. From a theoretical perspective, flood duration is an interesting quantity as it is like a fingerprint of a

\footnotetext{
${ }^{1}$ Department of Land and Water Resources Management, Faculty of Civil Engineering, Slovak University of Technology, Bratislava, Slovakia.

${ }^{2}$ Institute for Hydraulic and Water Resources Engineering, Vienna University of Technology, Vienna, Austria.

${ }^{3}$ Department of Catchment Hydrology, Helmholtz Centre for Environmental Research (UFZ), Halle, Germany.
}

Copyright 2012 by the American Geophysical Union 0043-1397/12/2011WR011509 catchment because it incorporates many aspects of runoff generation and precipitation characteristics. One would therefore like to understand the processes controlling flood duration in a given hydroclimatic and physiographic setting. Also, the inter-relationship between the characteristic time and space scales of floods is of considerable interest [Skøien et al., 2003] as is the assessment of regional similarities of floods in the context of predictions in ungauged catchments.

[3] Although the duration of a flood is arguable, the second most important quantity in flood hydrology (after the peak flow) is, surprisingly, little research has been devoted to understanding the processes driving flood duration. At a basic level it is clear that floods in, for example, a very small urban catchment induced by a convective event may only last for a couple of minutes while floods in some of the largest rivers of the world may last for weeks. At a more quantitative level it is similarly clear that the duration of a flood is (1) related to the duration of the meteorological input (rainfall, snowmelt), and (2) to the delay of this input in the catchment, both on the hillslopes and in the channels [Viglione et al., 2010a, 2010b].

[4] (1) The duration of the meteorological input: For a given catchment, the storm duration is directly related to flood duration. Short convective events will produce short 
floods, longer synoptic events or snowmelt-induced events will produce longer floods in the same catchment. This relationship is, in its simplest form, embodied in the unit hydrograph concept, and in more elaborate versions in a host of event-based rainfall-runoff models [Borah, 2011]. The duration of rainstorms leading to a flood is, however, not independent of the delay in the catchment. Viglione and Blöschl [2009] derive relationships between the duration of flood-producing storms, the duration of all storms, and catchment-response time, and argues that the catchments acts as a filter, so durations similar to the response timescale of the catchment lead to larger floods than shorter and longer storms. The nature and duration of the meteorological input has been used to classify floods into flood types [e.g., Hirschboeck et al., 2000; Merz and Blöschl, 2003].

[5] (2) The delay in the catchment: The delay of the rainfall input within the catchment has been the topic of numerous engineering studies with the aim of obtaining formulae for estimating the response timescale in catchments where no runoff data are available. The most frequently used timescales of catchment response are the time of concentration (defined as the travel time from the hydraulically furthermost point in a watershed to the outlet), and the lag time (the time from the center of mass of excess rainfall to the hydrograph peak), and these two can be related [McCuen et al., 1984; Fang et al., 2005]. There are two main types of approaches to estimating the response times and these shed light on what factors are considered most important to control these timescales. The first group of methods is based on hydraulic relationships [e.g., Dooge, 2005]. The input parameters for these relationships fall in four groups: flow length, topographic slope, flow resistance, and water input (as an index of flow depth) as dictated by hydraulic relationships such as the kinematic wave. The four parameters are sometimes separately specified for sheet flow, concentrated flow, pipe flow, and channel flow but, often, only sheet flow on the hillslope and channel flow are distinguished [McCuen et al., 1984]. The roughness parameters for the hillslope are usually obtained from plot scale irrigation experiments [Yu et al., 2000] and sometimes from laboratory experiments [Zhang et al., 2007]. The assumption underlying these relationships is that the entire catchment acts like a plot, i.e., plot scale relationships can be upscaled to the catchment scale. This is not necessarily the case when more complex runoff processes, e.g., due to macropores, take place. The other assumption of these relationships is that the flow on the hillslopes is mainly overland flow and other runoff processes (e.g., subsurface stormflow) can be neglected. The hydraulic relationships are therefore best applicable to small urban catchments and small arid catchments (where soils are often of low permeability relative to the rainfall intensity), but they are sometimes applied to other conditions, which, however, makes their suitability questionable.

[6] The second group of methods is based on regression relationships with catchment attributes that can be readily obtained from maps or geographic information systems [McCuen et al., 1984; Sheridan, 1994; Melone et al., 2002; Fang et al., 2005]. The input parameters for these relationships fall in the same four groups: The first two are commonly found in regression equations: flow length (usually indexed by the catchment area, which is often the parameter with the highest predictive power, or channel length instead of catchment area), and topographic slope (either related to the main channel or the entire catchment). The other two are less common: flow resistance (indexed by land use, urbanization, or a storage parameter) [Folmar et al., 2007] and water input (indexed by rainfall depth) [Rao et al., 1972]. Sometimes more complex catchment attributes are used that relate to landscape evolution such as drainage density and the hypsometric form of the catchment [Corradini et al., 1995; Sefton and Howarth, 1998; Harlina, 1984]. The relevant attributes and regression coefficients are obtained by graphical and regression analyses of observed runoff lag times against the catchment attributes. The advantage of regression relationships is that they may include the summary effect of a range of runoff processes (not just overland flow). The disadvantage is that they are only applicable to the hydrological regime they have been derived for. For example, for small forested catchments on Vancouver island, Loukas and Quick [1996] observed lag times about an order of magnitude larger than those estimated with the Kirpich [1940] equation derived from agricultural watersheds in Tennessee. Different equations have therefore been developed for rural [McEnroe and Zhao, 1999], urban [McCuen et al., 1984], flatland [Sheridan, 1994], and forested [Loukas and Quick, 1996] catchments as well as for different countries around the world. In a number of engineering studies, catchments have been grouped into regions with similar flood response. For instance, in South Africa, about nine dimensionless unit hydrographs have been identified that are used for flood estimation in ungauged catchments on the basis of similarity in hydrologic characteristics [Smithers, 2011]. To our knowledge, no studies have been published that provide a successful generalization of regression relations for different hydroclimatic conditions.

[7] An important reason for the inability of generalization and the lack of consensus on what are the most important controls on flood duration are the complexities of the runoff generation processes. In reality, the temporal patterns of flood flows are dominated by the temporal behavior of the precipitation forcing and the hydrological processes at various timescales, not only by the routing of surface runoff, and this is modulated by evaporation at various timescales. Water can reach stream channels via different flow paths including overland and shallow subsurface flow as well as deeper groundwater flow, typically at larger scales. Runoff response timescales are then a mix of the soil moisture and groundwater response timescales, which can span orders of magnitude. Dunne [1978], for example, noted that lag times related to subsurface stormflow can be 20-40 times larger than those of overland flow for the same catchment size. It is clear that, in the general case, the timing of flood response, and therefore the flood duration, is the result of the complex interplay of numerous factors.

[8] The aim of this paper is to shed light on the controls on flood duration that go beyond the simple morphometric characteristics used in the engineering hydrology literature and account for a wider spectrum of processes. Specifically, we aim to identify the magnitudes of flood timescales in the case study region as a function of flood processes, and isolate the controls that affect the flood timescales, in particular the relative role of climatic and catchment processes. The focus is on maximum annual floods, i.e., those 
floods in a catchment that produce the largest peak discharge in each year. Following Bell and Kar [1969], we use the ratio of flood volume and flood peak as a characteristic timescale of the flood duration, termed "flood timescale" $T_{Q}(\mathrm{~h})$, and similar timescales $T_{P}(\mathrm{~h})$ and $T_{C}(\mathrm{~h})$ to characterize rainfall duration and catchment response time, respectively. The analyses of the controls on the flood timescales are based on the concept of comparative hydrology [Falkenmark and Chapman, 1989]. Rather than modeling a single catchment in detail, we compare catchments with contrasting characteristics in order to understand the controls in a holistic way. As Sivapalan [2009, p. 1395] suggested, "Instead of attempting to reproduce the response of individual catchments, research should advance comparative hydrology, aiming to characterize and learn from the similarities and differences between catchments in different places, and interpret these in terms of underlying climatelandscape-human controls." This is what the paper tries to achieve for the case of flood timescales.

[9] In light of the above discussion, we believe, that the timescale characteristic used in this paper is a theoretically useful value that acts like a fingerprint of a catchment because it incorporates many aspects of runoff generation such as soils, geology, slope, and land use, precipitation amount and duration, timing of peak rainfall intensity, and antecedent precipitation [Hood et al., 2007], and also allows us to avoid the pitfalls inherent in using more complex approaches.

\section{Study Region and Data}

[10] The study region is Austria, which is hydrologically quite diverse, ranging from lowlands in the east to high alpine catchments in the west. Elevations range from $<200 \mathrm{~m}$ above sea level to $>3000 \mathrm{~m}$. Mean annual precipitation is $<400 \mathrm{~mm} \mathrm{yr}^{-1}$ in the east and almost $3000 \mathrm{~mm} \mathrm{yr}^{-1}$ in the west. Land use is mainly agricultural in the lowlands, forested in the medium elevation ranges, while alpine vegetation and rocks prevail in the highest catchments. Because of the diversity of hydrological processes, flood generating mechanisms vary substantially across Austria [Merz and Blöschl, 2003, 2009a; Parajka et al., 2010]. In the Alps in the west of Austria, streamflow variability and floods are strongly affected by snow and glacier melt. Most of the floods occur in summer as a result of frontal events, sometimes combined with local convective events. Snowmelt prior to the floods may enhance antecedent soil moisture when floods occur in early summer. In the lower alpine region south of the Alps (including East Tyrol, the Gail river) snow is similarly important and snowmelt-dominated floods often occur in May. However, the largest floods are caused by storm tracks from the Mediterranean and occur in autumn. In the lower alpine region at the northern fringe of the Alps, rainfall is high because of the orographic barrier of the Alps to northwesterly airflows. Most of the floods occur in summer as a result of frontal events with little or no contribution of snowmelt. In the northern lowlands, in contrast, rainfall is lower and floods may occur in both summer and winter. The winter floods are usually induced by rain-on-snow processes when antecedent snowmelt saturates the soils and relatively low rainfall intensities may then cause significant floods. In the very east of
Austria, annual rainfall is low and floods usually occur in summer as a result of frontal events, sometimes combined with local convective events. The southeast of Austria is hilly and conducive to convective events. In small catchments, in particular, the largest floods are produced by convective events in summer. Figure 1 top shows the average duration of extreme storms that have produced a maximum annual flood in Austria. The lower alpine region at the northern fringe of the Alps exhibits the longest durations, which is a reflection of orographic and synoptic rainfall. In the southeast of Austria, in contrast, the flood-producing storms tend to be short, which is a reflection of convective storms.

[11] Flood response in Austria is also significantly controlled by the geology (see Figure 1, center, for a map of the geology). Flysch tends to produce very flashy response as the flow paths are at the surface or very near the surface with little infiltration. Phyllite is usually deeply weathered causing deep flow paths and slow response. Similarly, gravel and sand tend to be associated with high permeabilities causing deep percolation into regional aquifers reducing the peaks and delaying the flood response.

[12] In this paper, hourly discharge data from 396 Austrian catchments for the observation period 1971-2007 were used. The catchment areas range from 5 to $\sim 10,000 \mathrm{~km}^{2}$ with a median of $140.1 \mathrm{~km}^{2}$. From this data set, the annual maximum floods were identified resulting in a total of 9223 events, which were used in this paper. The number of flood events per catchment ranged from 12 to 31 . To analyze the runoff response, hourly rainfall data from 143 recording stations (hourly resolution) were combined with daily rainfall data from 1066 stations. For details of the database see Merz et al. [2006]. Merz and Blöschl [2003] identified the types of causative mechanisms of floods which were also used here. The types were long-rain floods, short-rain floods, flash floods, rain-on-snow floods, and snowmelt floods. They used a combination of a number of process indicators including the timing of the floods, storm duration, rainfall depths, snowmelt, catchment state, runoff response dynamics, and spatial coherence. The flood types defined this way are used in this paper to link the flood timescales with the dominating hydrological processes. All analyses in this paper are performed at a time step of $1 \mathrm{~h}$.

\section{Methods}

[13] The timescales were estimated by analyzing the hyetographs and hydrographs of the 9223 maximum annual floods based on the method of Merz et al. [2006]. In a first step, the direct runoff and the base flow were separated using the automated method of Chapman and Maxwell [1996]. The parameters of the automatic filter were calibrated manually by visual inspection of the runoff data time series in each catchment. In a second step, the start and the end of the rainfall-runoff events were identified. For each peak flow, the start of an event was searched within a given time period by finding the time where the direct runoff becomes lower than a given threshold, which depends on the direct runoff at the time of the peak flow. The end of an event was found by a similar procedure [Merz et al., 2006]. Events that could not be clearly defined (e.g., multiple peak events without snow) were not used in 
- 15 to $120 \mathrm{~min}$.

$\Delta 120$ to $1440 \mathrm{~min}$.

1440 to $2880 \mathrm{~min}$.
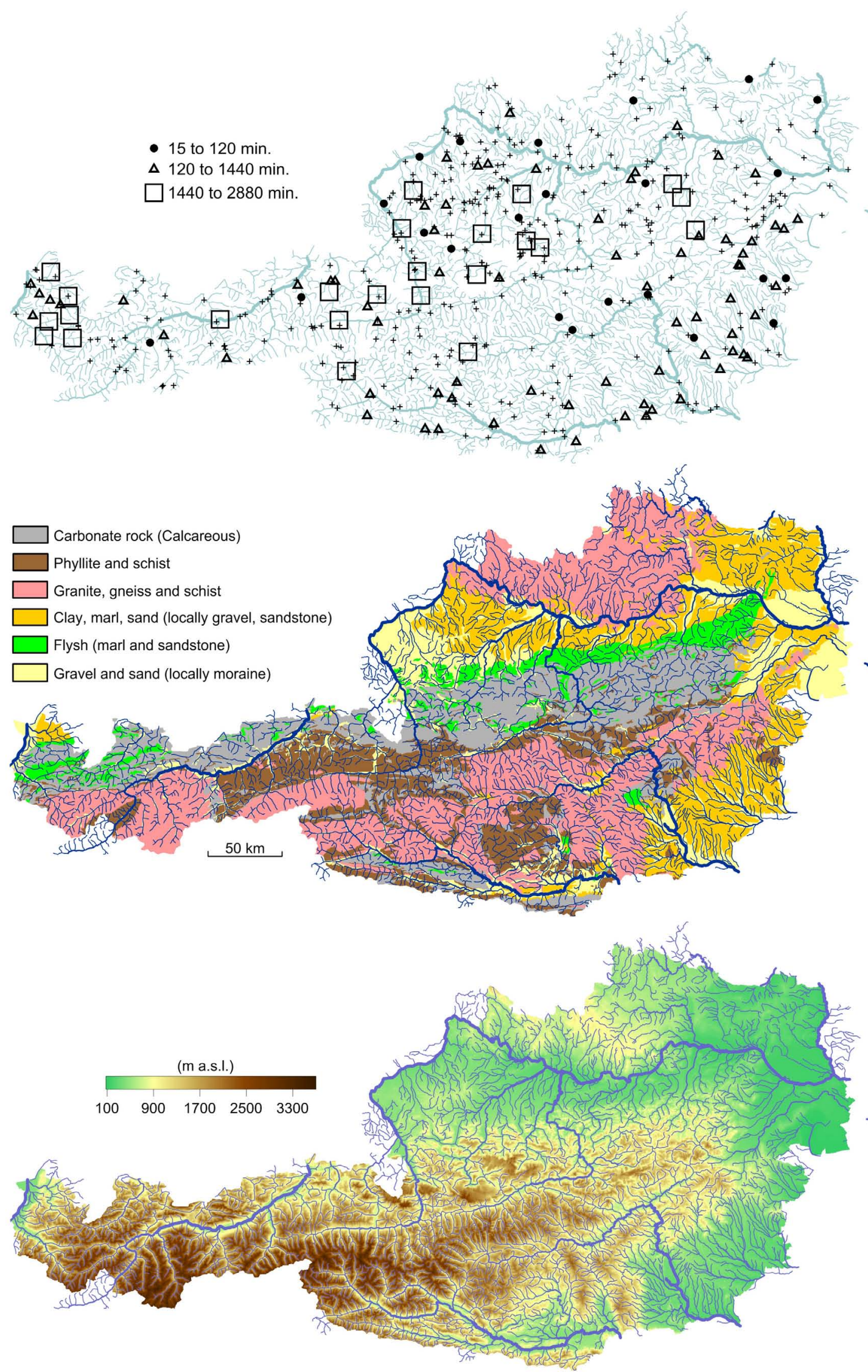

Figure 1. (top) Average duration of extreme storms that have produced a maximum annual flood in Austria. Crosses are stations where no extreme storms have been observed [Merz and Blöschl, 2003]. (center) Geology of Austria. (bottom) Topography of Austria. 
the analysis. In a third step, a simple rainfall-runoff model was fitted to the direct hydrograph. As an input to the rainfall-runoff model, catchment rainfall $i_{c}\left(\mathrm{~mm} \mathrm{~h}^{-1}\right)$, with an hourly time resolution, was estimated from a combined data set of hourly and daily rainfall data including simulated snowmelt. Snowmelt was simulated by the degree day factor concept [Merz et al., 2006]. The rainfall-runoff model was based on a linear reservoir with storage parameter $T_{c}(\mathrm{~h})$ and an event runoff coefficient $r_{c}(-)$ :

$$
Q(t)=r_{c} \int_{0}^{t} T_{c}^{-1} \cdot e^{-(t-\tau) \times T_{c}^{-1}} \cdot i_{c}(\tau) d \tau .
$$

[14] $T_{c}$ and $r_{c}$ were calibrated by minimizing the rootmean-square difference between the observed direct runoff hydrograph and the simulated direct runoff hydrograph $Q(t)\left(\mathrm{mm} \mathrm{h}^{-1}\right)$. The runoff coefficient $r_{c}$ was used to estimate the volume of the direct runoff $V_{f}(\mathrm{~mm})$ as

$$
V_{f}=P_{c} \cdot r_{c}
$$

where $P_{C}(\mathrm{~mm})$ is the catchment rainfall depth. The latter step yields more accurate volume estimates of the flood events than when integrating the observed direct runoff hydrograph directly, as the latter will invariably underestimate the volumes since the trailing limb is cut off at the end of the event. On the basis of these analyses, we defined the flood timescale $T_{Q}(\mathrm{~h})$ as the ratio between the flood volume $V_{f}$ and flood peak $Q_{f}\left(\mathrm{~mm} \mathrm{~h}^{-1}\right)$ :

$$
T_{Q}=V_{f} / Q_{f} .
$$

[15] Figure 2 gives two examples of flood hydrographs that have the same peak but differ in terms of their volume and therefore their flood timescales $T_{Q}$. For a triangular flood hydrograph, $T_{Q}$ corresponds to half the base of the event.

[16] Viglione et al. [2010b, p. 227; 2010a, p. 203] noted that there exists an almost $1: 1$ relationship between $T_{Q}$ and the square root of the variance of the timing of runoff $\operatorname{Var}\left(t_{Q}\right)$ (i.e., the temporal dispersion of the runoff hydrograph):

$$
\operatorname{Var}\left(t_{Q}\right)=\frac{\int_{0}^{\infty}\left[\tau-\mathrm{E}\left(t_{Q}\right)\right]^{2} \cdot Q(\tau) d \tau}{\int_{0}^{\infty} Q(\tau) d \tau}
$$

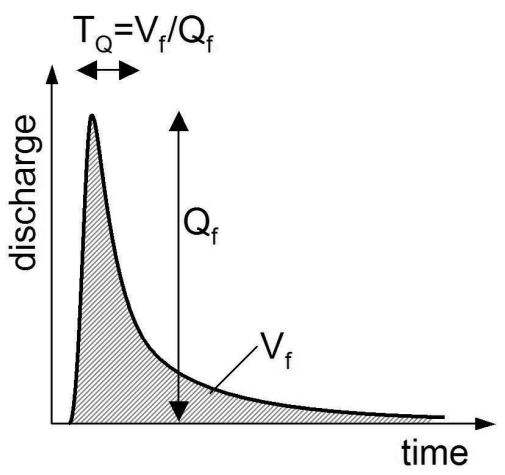

with

$$
\mathrm{E}\left(t_{Q}\right)=\frac{\int_{0}^{\infty} \tau \cdot Q(\tau) d \tau}{\int_{0}^{\infty} Q(\tau) d \tau}
$$

where $Q\left(\mathrm{~mm} \mathrm{~h}^{-1}\right)$ is direct runoff and $t_{Q}(\mathrm{~h})$ is the timing of the runoff. However, equation (3) was preferred in this paper as it can be estimated more robustly since it avoids the problem of truncated trailing limbs of the hydrographs.

[17] In order to obtain a measure of the rainfall duration, catchment precipitation (including snowmelt) was analyzed for all events and the precipitation timescale, $T_{P}(\mathrm{~h})$, and was estimated following Viglione et al. [2010a] as

$$
T_{P}=\sqrt{\operatorname{Var}\left(t_{P}\right)}
$$

with

$$
\operatorname{Var}\left(t_{P}\right)=\frac{\int_{0}^{\infty}\left[\tau-\mathrm{E}\left(t_{P}\right)\right]^{2} \cdot i(\tau) d \tau}{\int_{0}^{\infty} i(\tau) d \tau}
$$

and

$$
\mathrm{E}\left(t_{P}\right)=\frac{\int_{0}^{\infty} \tau \cdot i(\tau) d \tau}{\int_{0}^{\infty} i(\tau) d \tau},
$$

where $i\left(\mathrm{~mm} \mathrm{~h}^{-1}\right)$ is the rainfall intensity at a representative rain gauge for each catchment, and $t_{P}(\mathrm{~h})$ is the time into the storm.

[18] In summary, three timescales were identified for all 9223 annual maximum floods: the precipitation timescale, $T_{P}$, which represents a characteristic duration of the rainfall event producing a maximum annual flood in the catchment; the catchment response timescale, $T_{C}$, which represents the time delay of the catchment routing consistent with the time parameter of a linear reservoir; and the flood timescale, $t_{q}$, which is a measure of the duration of the flood (equation (3)).

[19] The above analysis assumed that rainfall is spatially uniform in the catchment, and the rainfall-runoff system is

Figure 2. Illustration of the flood timescale $T_{Q}$. 
fully linear with an exponential unit hydrograph with time constant $T_{C}$. Based on the analyses of different event types, Viglione et al. [2010b] found that these assumptions are a good approximation for the purpose of estimating timescales. With these assumptions,

$$
T_{Q}^{2}=T_{P}^{2}+T_{C}^{2}
$$

[20] This is because, $T_{Q}^{2}$ can be approximated by the variance of the timing of runoff (equation (4a)), $T_{P}^{2}$ is defined as the variance of the timing of rainfall (equation (5a)), $T_{C}^{2}$ is the variance of the timing of the exponential unit hydrograph, and the variances are additive under these assumptions (equation (14) in the work of Viglione et al. [2010b]). Equation (6) is used in the paper to check the consistency of the timescales.

[21] In a first analysis step, the spatial patterns of the basic statistics (location, spread) of the flood timescales $T_{Q}$ are examined visually and the relationship with the catchment area is examined. To allow for a more elaborate description of the differences in hydrological response between and within the regions, in the next level of the analysis we concentrated on several groups of catchments which we term "hot spots." These are regions where the flood-generating mechanisms are considered rather uniform within the region but quite different from other regions. These hot spots can be considered as end members of the spectrum of flood-generating mechanisms in Austria. Thirteen hot spots were selected based on the requirements that the catchments within a given hot spot were similar from a hydrologic perspective (geology, hydro-climatic characteristics) and the hot spots as a whole provided a set of contrasting groups of runoff response. Each hot spot contained between four and seven catchments with a total of 70 catchments in all 13 hot spots. A detailed procedure of how the hot spots were selected is given in Appendix B; detailed information on the hot spots is given in Table B1.

[22] Based on the concepts of comparative hydrology [Falkenmark and Chapman, 1989], the flood characteristics of the hot spots can be compared to learn from the differences between them. For each hot spot, the cumulative distribution functions of the flood timescales $T_{Q}$ and the shapes of the flood hydrographs are examined. Both analyses are stratified in terms of the season of occurrence of the flood events and according to the flood types defined by Merz and Blöschl [2003] to link the flood timescales to the dominating hydrological processes. In a final analysis step, the flood timescales $T_{Q}$ are compared with the precipitation timescales $T_{P}$ and the catchment response timescales $T_{C}$, and interpreted in terms of process controls.

\section{Results}

\subsection{Flood Timescales}

[23] The median flood timescale $\tilde{T}_{Q}$ (h) for each catchment is plotted in Figure 3 against a catchment area. $\tilde{T}_{Q}$ ranges between 7 and $146 \mathrm{~h}$. There is a tendency of $\tilde{T}_{Q}$ to increase with area but the correlations are not very strong. The Pearson correlation coefficient between $\tilde{T}_{Q}$ and the logarithm of a catchment area is $R=0.45$ (i.e., $R^{2}=0.20$, Table A1). More interestingly, the pattern in Figure 3 indicates that the dependence is mainly related to the fact that for large catchments short $\tilde{T}_{Q}$ do not exist. Clearly, whatever the processes, large catchments will have a minimum flood timescale $(\sim 50 \mathrm{~h}$ as shown in Figure 3$)$. This is reminiscent of a lower threshold of storage parameters in continuous rainfall-runoff models as a function of catchment scale (Figure $7 \mathrm{~b}$ in the work of Merz et al. [2009]). However, for a given catchment area of, for example, $100 \mathrm{~km}^{2}, \tilde{T}_{Q}$ ranges from 7 to $150 \mathrm{~h}$. The correlations with other catchment attributes are not very large either (Table A1). For example, the (univariate) correlations with stream network density and mean catchment slope are $R^{2}=0.04$ and 0.03 , respectively. Bivariate correlations with catchment area and soil type give $R^{2}=0.25$, and the correlations for other attributes are shown in Table A1. A rank correlation analysis (not shown here) gives similar magnitudes of the correlation coefficients. Clearly, the relationship of the flood timescales with catchment and climate characteristics is more complex than can be represented by regression equations.

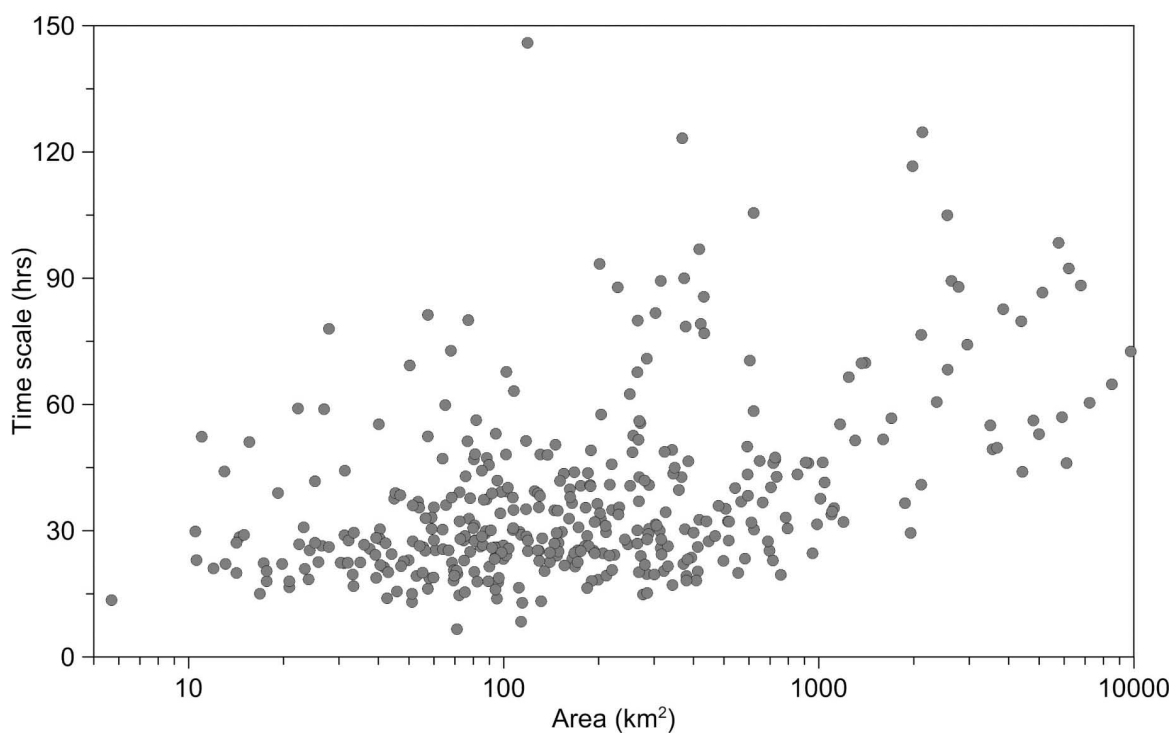

Figure 3. Median of flood timescales $\tilde{T}_{Q}$ in Austria plotted versus catchment area $\left(\mathrm{km}^{2}\right)$. 


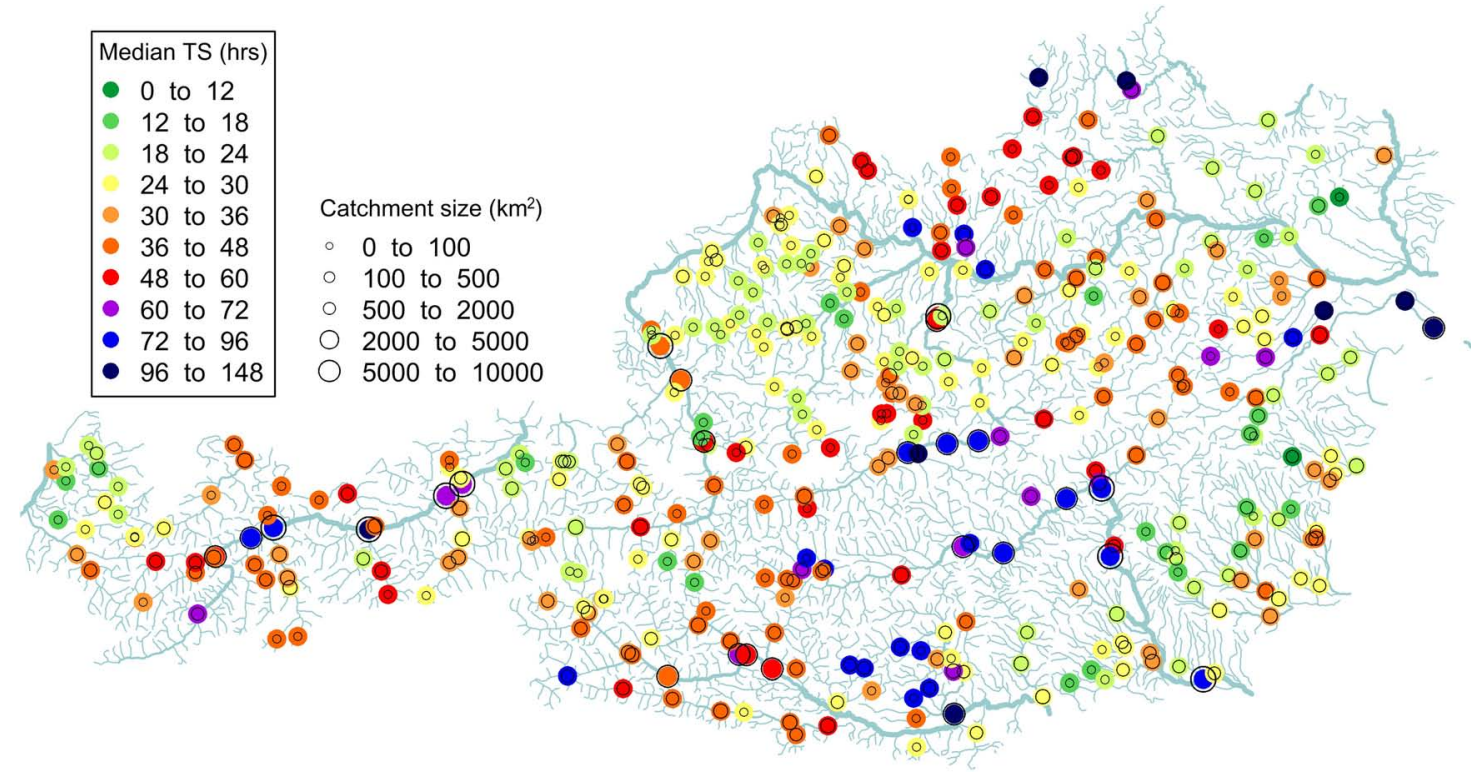

Figure 4. Median of flood timescales $\tilde{T}_{Q}$ in Austria.

[24] Geographically (Figure 4), small $\tilde{T}_{Q}$ tend to occur in the northwest (Innviertel), the northeast (Weinviertel), the southeast (Styria), the extreme west (Bregenzwald), as well as along the northern slopes of the alpine range in the middle of the country. The largest values of $\tilde{T}_{Q}$ may be directly associated with the largest rivers (Inn, Enns, Mur). Furthermore, a group of catchments with large $\tilde{T}_{Q}$ is located in the south of the country (Gurktal) as well as the flatlands of the extreme east. The pattern in Figure 4 is quite complex and reflects the interactions between the climatic flood-driving mechanisms and the geological setting. To better understand the processes leading to these timescales, in the remainder of the study we focus on the hot spots shown in Figure 5. The colors in Figure 5 indicate the average timing of the floods within the year (see equation (4) by Parajka et al. [2010]).
[25] The cumulative distribution functions (CDFs) of the flood timescales were examined in the individual catchments of the hot spots (gray lines in Figure 6). Additionally, all events within a hot spot were pooled (red lines in Figure 6). The graphs are arranged in ascending order according to $\tilde{T}_{Q}$, from top left to bottom right. Table 1 presents the corresponding statistics for each hot spot.

[26] It is now of interest to understand the reasons for the differences in the flood timescales between the hot spots. Flood timescales are sometimes related to a catchment area because of the longer flow paths in larger catchments [e.g., Melone et al., 2002]. Figure 7 therefore, examines the effect of a catchment area on the flood timescales. The hot spots are color-coded from green to blue (and black) in ascending order of the median flood timescales. Figure 7 indicates that the timescales do not depend much on

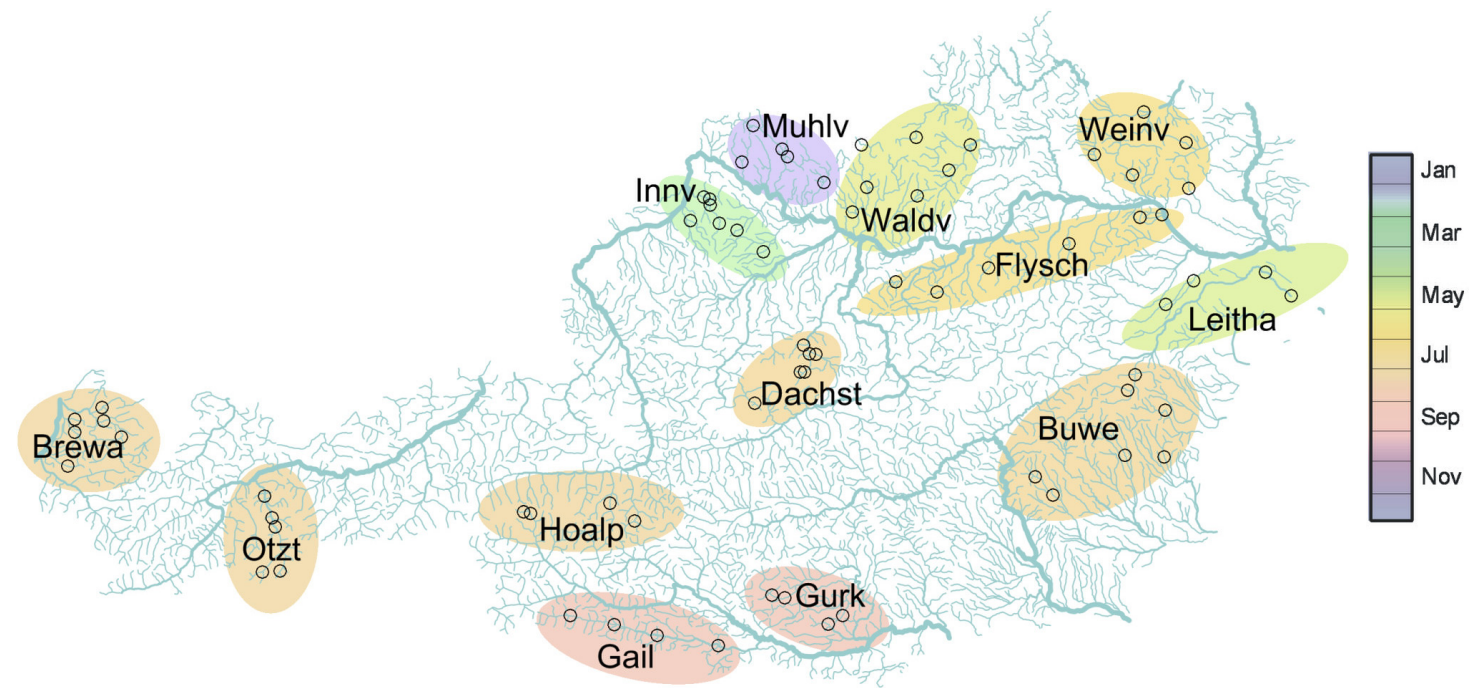

Figure 5. Location of the selected hot spots and the corresponding catchments. Colors indicate mean month of flood occurrence. 

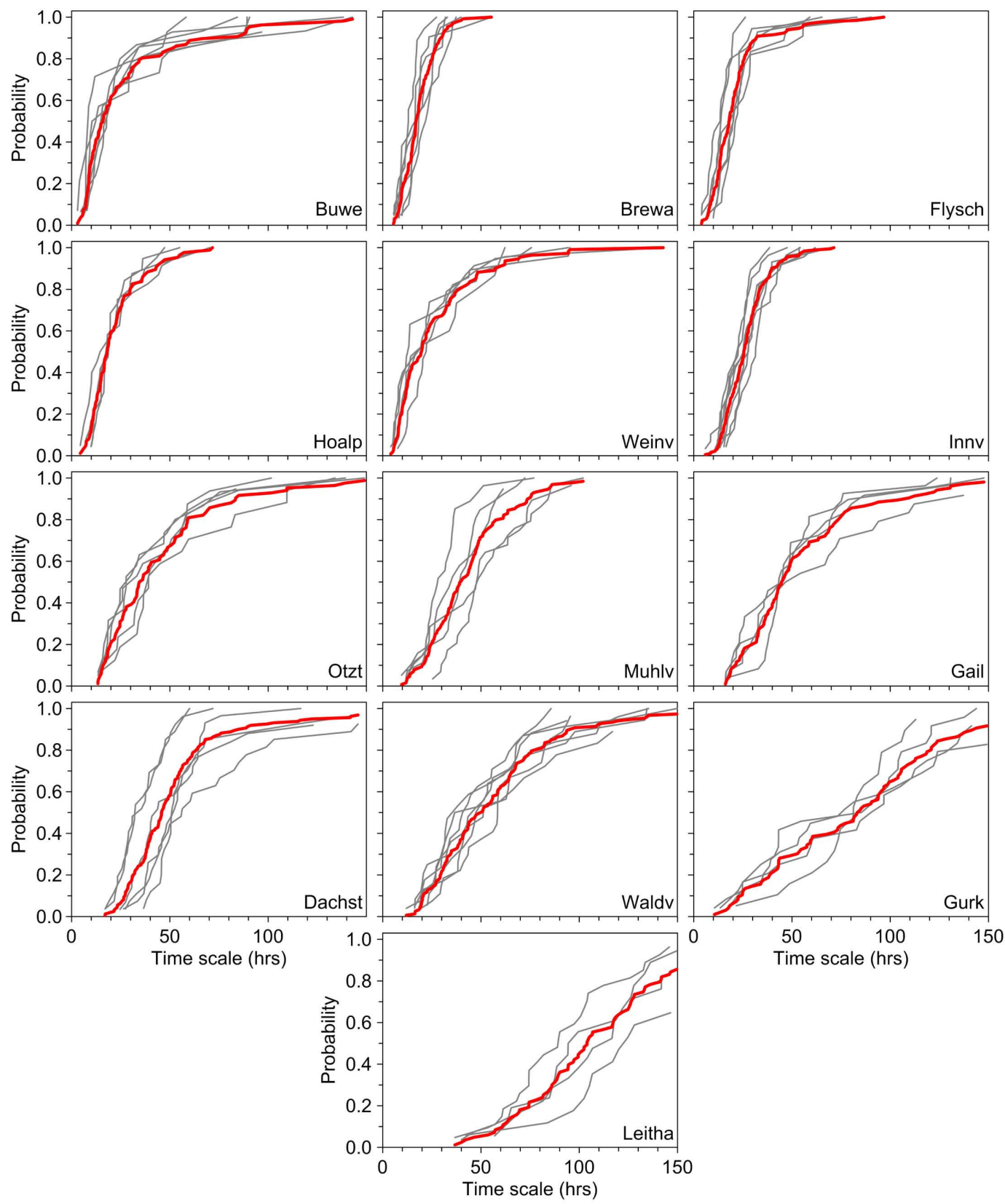

Figure 6. Cumulative distribution functions (CDFs) of the flood timescales $T_{Q}$ of the hot spots. Thin gray lines denote CDFs of individual catchments; thick red lines denote CDFs of merged data of all catchments within a hot spot.

catchment area. There is a slight increase of $\tilde{T}_{Q}$ in some of the hot spots (e.g., Flysch, Innv, Leitha), but the differences between the hot spots are much larger than would be explained by the catchment area. Apparently, other controls are much more important.

[27] One would expect two main groups of controls to be important for the flood timescales. The first group is related to climate and involves the prevalent type of precipitation such as convective and synoptic storms, and the presence of snowmelt and rain-on-snow events. The type of precipitation will affect the storm duration (and the spatial variability), which in turn will affect the flood timescale. The second group of controls is related to catchment processes and involves runoff generation processes such as surface versus subsurface flow, depending on soils and geology. The runoff processes may also include inundation processes and stream aquifer interactions, which may affect the shape of the flood hydrograph, and therefore the flood response time. We now examine time of the year, hydrograph shape, and flood process type to separate the effects of climate and geology on the flood response and interpret the processes involved.

[28] Flood hydrographs are plotted in Figure 8, and color-coded by the time of the year the flood occurred. For 
Table 1. Statistics of Flood Timescales $\left(T_{Q}\right)$ for the Selected Hot Spots ${ }^{\mathrm{a}}$

\begin{tabular}{|c|c|c|c|c|c|c|}
\hline Hot Spot & Selected Hot Spot & Abbreviation & Mean $T_{Q}(\mathrm{~h})$ & Coeff. of Var. of $T_{Q}$ & Median $T_{Q}(\mathrm{~h})$ & $\operatorname{IQR} T_{Q} / \operatorname{Median} T_{Q}$ \\
\hline 1 & Bucklige Welt & Buwe & 28.4 & 1.136 & 15.9 & 1.364 \\
\hline 2 & Bregenzwald & Brewa & 18.5 & 0.456 & 16.9 & 0.646 \\
\hline 3 & Flysch & Flysch & 21.3 & 0.722 & 18.1 & 0.636 \\
\hline 4 & Hochalpen & Hoalp & 22.2 & 0.635 & 18.1 & 0.776 \\
\hline 5 & Weinviertel & Weinv & 26.7 & 0.872 & 19.8 & 1.196 \\
\hline 6 & Innviertel & Innv & 26.8 & 0.419 & 25.5 & 0.550 \\
\hline 7 & Ötztal & Ötzt & 45.5 & 0.704 & 35.3 & 0.980 \\
\hline 8 & Mühlviertel & Mühlv & 44.5 & 0.576 & 39.8 & 0.650 \\
\hline 9 & Gail & Gail & 54.8 & 0.608 & 45.0 & 0.804 \\
\hline 10 & Dachstein & Dachst & 53.0 & 0.561 & 45.8 & 0.519 \\
\hline 11 & Waldviertel & Waldv & 57.0 & 0.592 & 50.3 & 0.794 \\
\hline 12 & Gurktal & Gurk & 84.7 & 0.569 & 83.8 & 0.830 \\
\hline 13 & Leitha & Leitha & 110.7 & 0.390 & 104.0 & 0.488 \\
\hline
\end{tabular}

${ }^{\text {a } T h e ~ s t a t i s t i c s ~ a r e ~ e s t i m a t e d ~ f r o m ~ a l l ~ c a t c h m e n t s ~ i n c l u d e d ~ i n ~ a ~ p a r t i c u l a r ~ h o t ~ s p o t . ~ T h e ~ h o t ~ s p o t s ~ a r e ~ r a n k e d ~ a c c o r d i n g ~ t o ~ t h e ~ m e d i a n ~ o f ~} T_{Q}\left(\right.$ i.e. $\tilde{T}_{Q}$ ). Abbreviations: coeff. of var.: coefficient of variation, IQR: interquartile range ( $75 \%-25 \%$ percentile).

each hot spot one catchment was selected for clarity and all of the recorded flood hydrographs of the maximum annual floods are shown. In the Buwe hot spot, the shape of most hydrographs is very flashy. Most of the events occur in summer. Clearly, in this catchment the maximum annual floods are mostly produced by convective storms. Brewa is similar, but there are also some autumn floods and the events tend to be a little less flashy. The Flysch hot spot has many summer events. There are also some winter events which seem to be all similar and less flashy. Hoalp has almost only summer events, similar to Ötzt. This is because of the high elevation of the catchments where precipitation falls, at least partly, as snow during the rest of the year. Weinv has floods throughout the year. The spring floods are apparently associated with snow as indicated by the daily cycle of some of the events. In this hot spot, the meteorological forcing appears to be due to a range of processes including convective storms in summer as indicated by the slim shape of some of the summer hydrographs. The Innv catchments have even more winter floods. Mühlv is similar to Innv with numerous winter events, but a tendency for larger $T_{Q}$. The Gail region is interesting in that there are some winter and summer floods, but most of the floods occur in autumn, in particular the large floods. The timescales of most floods are rather long. The Dachst catchments mostly have summer floods with some autumn floods, while the Waldv catchments feature a number of short summer floods, and much longer spring floods, which may be related to snow or rain-on-snow processes. The Gurk floods occur in summer and autumn. The hydrograph shapes are not only elongated they also have a smooth shape. This suggests that the large timescales are mainly due to catchment delay rather than to long storm durations. It is the filtering of the catchments [Skøien and Blöschl, 2006] that is apparent in the hydrograph shapes which removes the fine timescale structure of the rainfall. The Leitha catchments, finally, have floods all around the year. They are all very long and very smooth. Again, the catchments seem to filter out the high frequency component of rainfall.

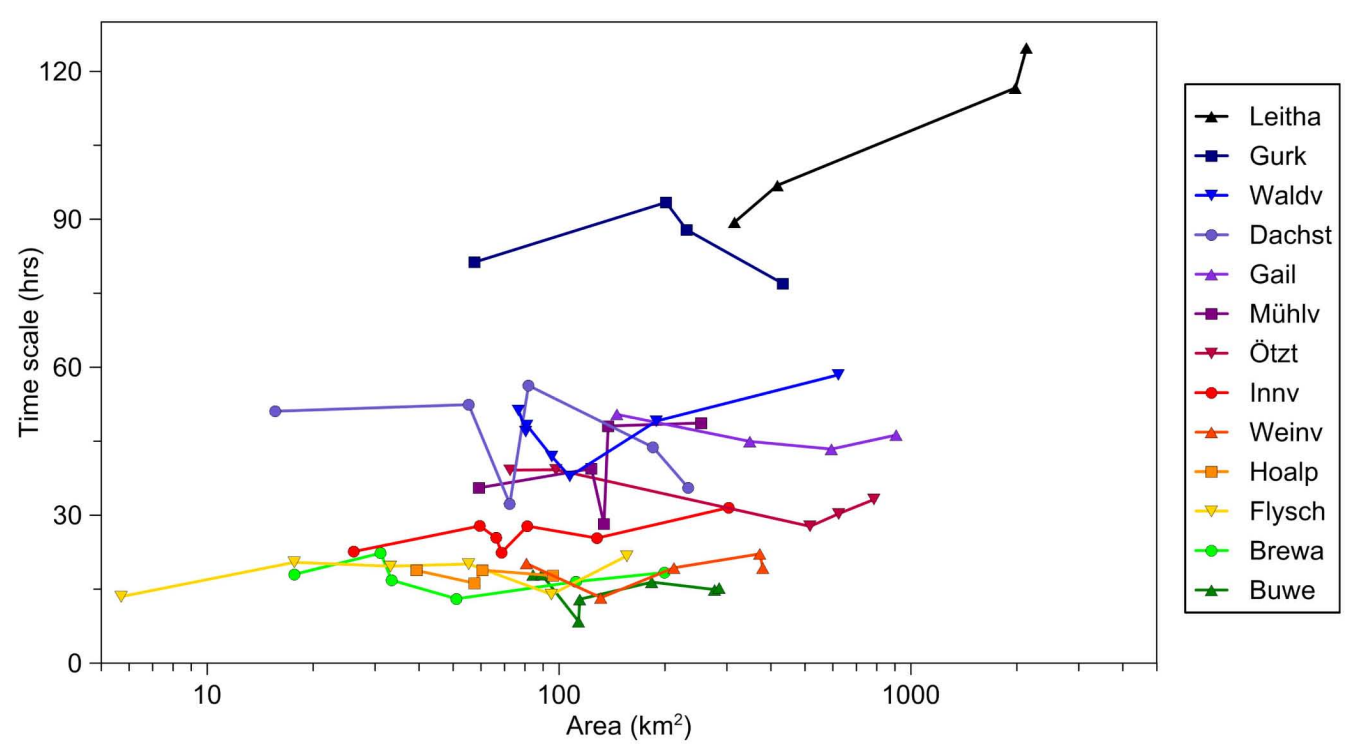

Figure 7. Median of flood timescales $\tilde{T}_{Q}$ for each catchment as a function of catchment area. Hot spots are color coded (see Table 1). 

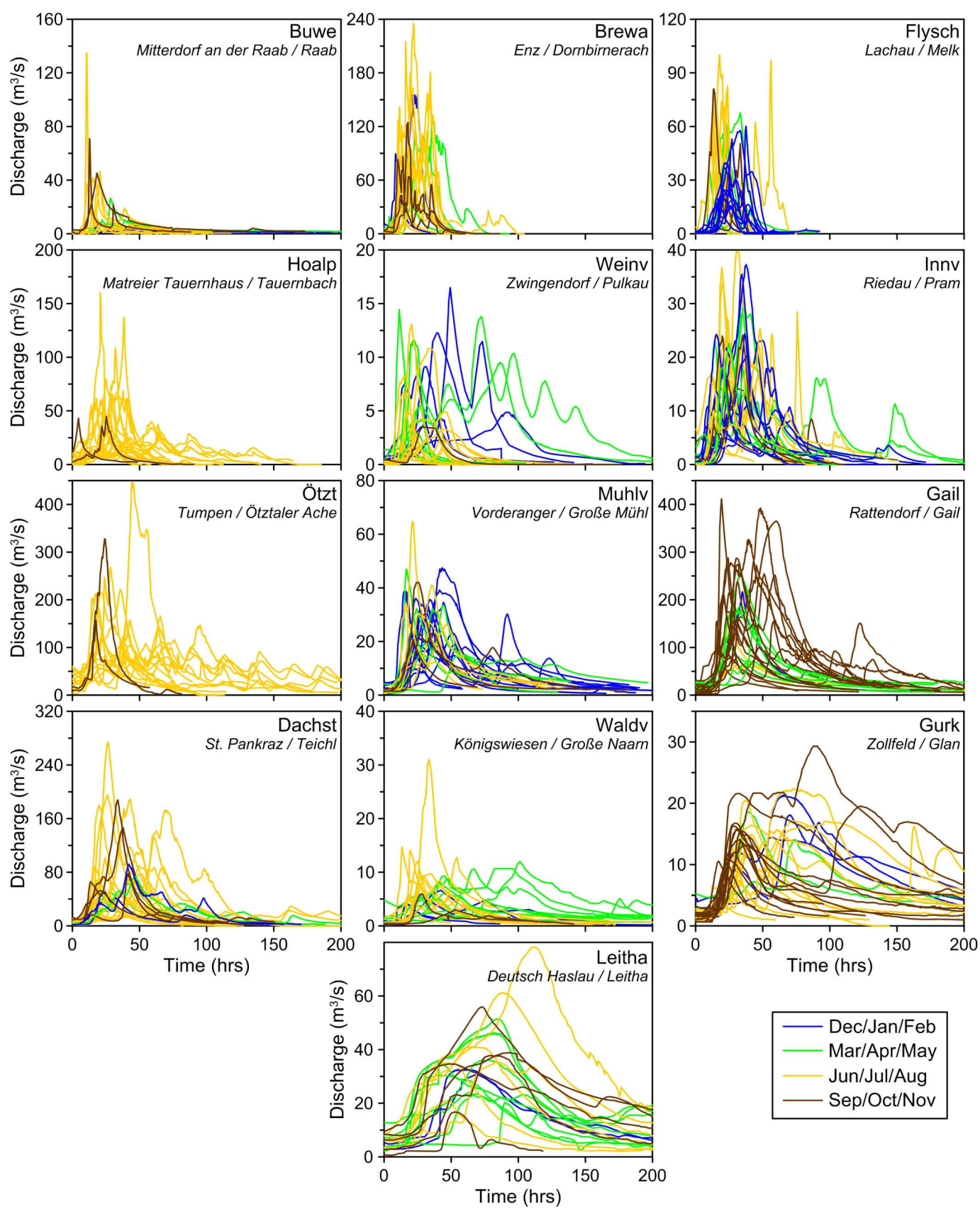

Figure 8. Hydrographs of direct runoff of annual maxima of flood peaks for selected catchments in each hot spot, color-coded by season of occurrence.

[29] To obtain a more comprehensive assessment of the seasonality of the floods the CDFs of the flood timescales stratified by the season were analyzed in Figure 9. In most hot spots the largest $T_{O}$ occur in spring (Buwe, Innv, Mühlv, Gail, Dachst, Waldv, Gurk). In Weinv, however, the largest $T_{O}$ occur in winter. The larger timescales in spring are likely related to snowmelt events which will lead to larger flood volumes than rain floods. The larger timescales in spring may also be related to higher antecedent soil moisture in spring than in summer. Soil moisture in spring may be high because of low evapotranspiration and because of snowmelt increasing soil moisture, but not directly contributing to the flood [Merz and Blöschl, 2009a]. High soil moisture states may increase the contribution of subsurface flow and hence the volume of floods [Komma et al., 2007]. The exception is Weinv, which is the lowest of the hot spots. In Weinv, the timescales are larger in winter, which is consistent with both winter snowmelt and high soil moisture in winter. The Brewa region is interesting in that the timescales are very similar all the year round. Brewa is the hot spot with the largest mean annual rainfall (Appendix A). The catchments therefore tend to be very wet all year round leading to similar flood timescales. Because of the high altitudes there are no winter and spring events in the Ötzt and Hoalp regions. 

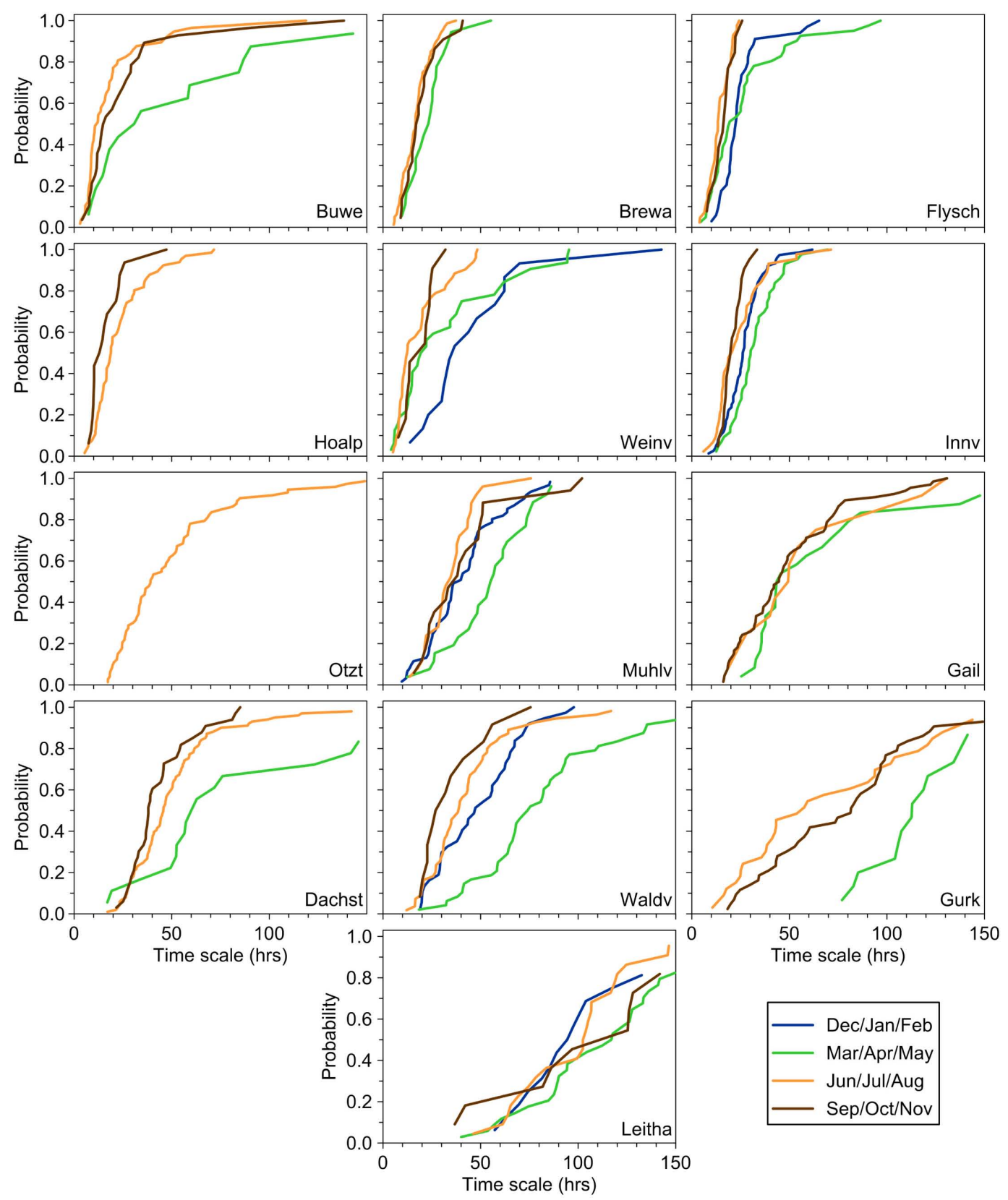

Figure 9. Cumulative distribution functions (CDFs) of flood timescales $T_{Q}$ in the individual hot spots, stratified by the season of occurrence. Only seasons with at least 10 events are shown.

[30] These interpretations can be examined by directly analyzing the flood process types as identified by Merz and Blöschl [2003]. Table 2 presents the frequency of occurrence (percentages) of annual maximum floods stratified by the season of occurrence (left) and the flood types (right). The annual floods in Austria generally occur most frequently in summer with the exception of Innv and Mühl, where winter floods are more frequent, and Gail and Gurk where autumn floods are more frequent. In most hot spots, long-rain floods are the most frequent flood types, but there are interesting differences between the hot spots of all flood types. Rain-on-snow floods are important in Innv and Mühl and these are mainly winter floods. In Flysch and Waldv there are rain-on-snow floods, which occur in both winter and spring. Weinv stands out for its large frequency of flash floods induced by convective events. The median flood timescales stratified by flood event type (Table 3) corroborate the findings of the previous figures. For a given hot spot, the highest median of $T_{Q}$ is generally associated with snowmelt floods (Buwe, Brewa, Hoalp, Weinv, Ötzt, Dachst, Waldv, Gurk, and Leitha). In some of the hot spots the flood timescales for snowmelt events are more than twice the timescales of the other event types. Rain-on-snow events often produce the second largest timescales. However, there are differences between the hot spots as to the relative magnitude of the rain-on-snow timescales and the rain floods. For Brewa and Innv the rain-on-snow timescales are similar to those of the rain floods. These two hot 
Table 2. Frequency of Occurrence (Percent) of Annual Maximum Floods Stratified by Season of Occurrence (Left) and Flood Types (Right) $)^{\mathrm{a}}$

\begin{tabular}{|c|c|c|c|c|c|c|c|c|c|c|}
\hline Percent & $\begin{array}{l}\text { Winter } \\
\text { (DJF) }\end{array}$ & $\begin{array}{c}\text { Spring } \\
\text { (MAM) }\end{array}$ & $\begin{array}{l}\text { Summer } \\
\text { (JJA) }\end{array}$ & $\begin{array}{l}\text { Autumn } \\
\text { (SON) }\end{array}$ & Percent & $\begin{array}{l}\text { Long-Rain } \\
\text { Flood }\end{array}$ & $\begin{array}{l}\text { Short-Rain } \\
\text { Flood }\end{array}$ & $\begin{array}{l}\text { Flash } \\
\text { Flood }\end{array}$ & $\begin{array}{l}\text { Rain-on-Snow } \\
\text { Flood }\end{array}$ & $\begin{array}{l}\text { Snowmelt } \\
\text { Flood }\end{array}$ \\
\hline 1 Buwe & 6 & 15 & 53 & 26 & 1 Buwe & 56 & 27 & 7 & 8 & 1 \\
\hline 2 Brewa & 7 & 14 & 62 & 17 & 2 Brewa & 62 & 19 & 0 & 16 & 2 \\
\hline 3 Flysch & 26 & 31 & 33 & 10 & 3 Flysch & 38 & 29 & 4 & 29 & 0 \\
\hline 4 Hoalp & 1 & 3 & 77 & 19 & 4 Hoalp & 58 & 35 & 2 & 2 & 2 \\
\hline 5 Weinv & 14 & 29 & 47 & 10 & 5 Weinv & 35 & 31 & 23 & 9 & 3 \\
\hline 6 Innv & 41 & 23 & 24 & 11 & 6 Innv & 44 & 16 & 0 & 40 & 1 \\
\hline 8 Mühlv & 47 & 20 & 19 & 13 & 8 Mühlv & 31 & 18 & 0 & 51 & 0 \\
\hline 9 Gail & 2 & 23 & 12 & 63 & 9 Gail & 52 & 28 & 0 & 20 & 0 \\
\hline 10 Dachst & 6 & 11 & 63 & 20 & 10 Dachst & 63 & 25 & 0 & 10 & 1 \\
\hline 11 Waldv & 24 & 32 & 36 & 8 & 11 Waldv & 42 & 17 & 1 & 39 & 1 \\
\hline 12 Gurk & 5 & 16 & 34 & 45 & 12 Gurk & 54 & 30 & 3 & 10 & 2 \\
\hline 13 Leitha & 19 & 41 & 27 & 13 & 13 Leitha & 48 & 14 & 0 & 37 & 0 \\
\hline
\end{tabular}

${ }^{\text {a} D J F}$, December-January-February; MAM, March-April-May; JJA, June-July-August; SON, September-October-November.

spots have high mean annual precipitation (in particular Brewa), so there may be not much difference between the antecedent soil moisture of the rain-on-snow floods and rain induced floods. In Buwe and Weinv, in contrast, the rain-on-snow timescales are significantly larger than those of the rain floods. Mean annual precipitation in these regions is lower than in Brewa, therefore the differences between wet soil states of rain-on-snow floods and possibly dryer soil states for rain floods become more apparent. As expected, the flash floods produce the smallest flood timescales (with one exception). The flash flood timescales are, in fact, very short (between 7 and $10 \mathrm{~h}$ for Buwe, Brewa, and Flysch). It is interesting that in the Gurk and Leitha hot spots, all flood types have long flood timescales. Even the flash floods in the Gurk region have median timescales of $41 \mathrm{~h}$. This is a clear indication that the larger timescales of Gurk and Leitha are not related to climate but rather to catchment and stream processes.

\subsection{Precipitation Timescales $T_{P}$ and Catchment Timescales $\boldsymbol{T}_{C}$}

[31] In order to assess the relative roles of rainfall and catchment processes Figure 10 shows the distributions of the flood timescales $\left(T_{Q}\right.$, red lines), catchment timescales $\left(T_{C}\right.$, blue lines), and precipitation timescales $\left(T_{P}\right.$, black lines).

[32] In the Buwe and Weinv hot spots, the precipitation timescales are very short which is consistent with the role of the flash floods as indicated in Tables 2 and 3. Some of the events are longer and these are mostly rain-on-snow events. For the other fast response catchments (Brewa, Flysch, Holap, and Innv) the storms are somewhat larger. For Ötzt, Mühlv, Dachst, and Waldv they are even larger and on the order of 20-30 h. In these catchments, rain-onsnow and long-duration storms are important and flash floods are less frequent or nonexistent giving rise to long durations of flood-producing storms or snowmelt events. Although the flood response timescales of the Gurk catchment are large, $T_{P}$ does not increase to the same extent. This implies that the large $T_{Q}$ are mainly a result of the delay within the catchment rather than a result of long storms. Similarly, $T_{Q}$ in the Leitha hot spot are much larger than the $T_{P}$ pointing to the dominant role of catchment processes leading to the very large delays in flood response.
[33] To test the relative role of catchment and precipitation timescales, the dashed line in Figure 10 shows the combination of $T_{P}$ and $T_{C}$ according to equation (6), which is an estimate of $T_{Q}$. The dashed line should therefore match with the red line of $T_{Q}$ if all the assumptions for equation (6) are satisfied and the data errors are small. For the flashy hot spots, the match is very good. In the Ötzt, Dachst, and Waldv hot spots, the combination of $T_{P}$ and $T_{C}$ underestimates $T_{Q}$ consistently. This may be partly related to the snowmelt estimates used for estimating $T_{P}$. If snowmelt is underestimated, $T_{P}$ will be underestimated and so will the combination of $T_{P}$ and $T_{C}$. For the slowest catchments (Gurk, Leitha) the match is good.

[34] The median timescales from Figure 10 were compiled in the schematic of Figure 11 for each hot spot. The small precipitation timescales $T_{P}$ between 3 and $7 \mathrm{~h}$ (Buwe, Weinv) occur in areas where convective storms are important for producing the maximum annual floods. The somewhat larger precipitation timescales occur where synoptic and orographic storms as well rain-on-snow events tend to play a more important role (Hoalp, Innv). For the Waldv, Mühlv, Ötzt, and Dachst catchments, significantly longer storms $(\sim 20 \mathrm{~h})$ and/or snowmelt events are important. Not only is the type of climatic forcing different from Buwe, for example, one would also expect that, because of the longer catchment lag times, longer storms become relatively more important. Finally, Gurk and Leitha exhibit some very long catchment timescales. The figure suggests that, depending on the hot spot, climate and catchment processes contribute with different magnitudes to the flood timescales. Indeed, the hot spots below the $1: 1$ line in Figure 11 (e.g., Ötzt, Mühlv) are those where the precipitation timescales $T_{P}$ are larger than the catchment timescales $T_{C}$, i.e., where meteorological forcing dominates the flood timescales. Conversely, the hot spots above the 1:1 line (e.g., Gurk, Leitha) are those where the $T_{C}$ are larger than the $T_{P}$, i.e., where catchment processes dominate the flood timescales.

\section{Discussion and Conclusions}

\subsection{Flood Generation Processes and Timescales}

[35] A number of regions or hot spots have been selected in the study domain to understand what the main drivers of 

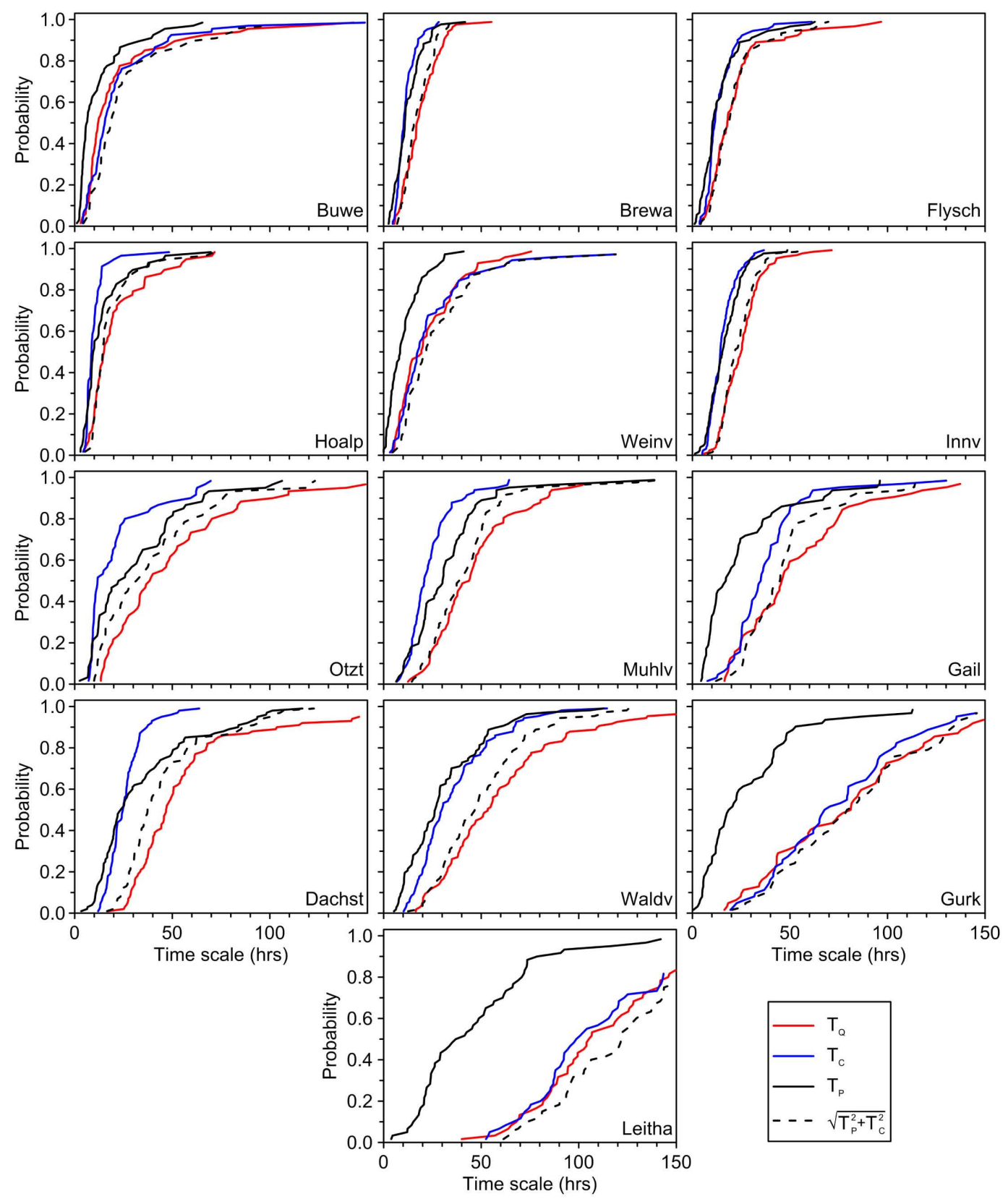

Figure 10. Cumulative distribution functions (CDFs) of flood timescales ( $T_{Q}$, red lines), catchment timescales ( $T_{C}$, blue lines), and precipitation timescales ( $T_{P}$, black lines). The dashed line is the combination of $T_{P}$ and $T_{C}$ and should match the red line of $T_{Q}$.

flood timescales are. We apply the concept of comparative hydrology to learn from the differences between the hot spots about the main flood-producing processes and what their effects are on flood timescales. The comparison of the processes is summarized in Table 4.

[36] The median flood timescales $\tilde{T}_{Q}$ of the hot spots range from $16 \mathrm{~h}$ in the Buwe to $104 \mathrm{~h}$ in the Leitha regions. The range is even larger for different flood types, from $7 \mathrm{~h}$ for flash floods in the Buwe catchments to $200 \mathrm{~h}$ for snowmelt floods in the Gurk catchments. In the catchments with the fastest response (Buwe), convective storms are important for the maximum annual floods. The hydrograph shapes are very flashy, which suggests that catchments are often only partly covered by rainfall, so the average flow path lengths to the catchment outlet may be short. The hot spot (Buwe) with the largest variability of $T_{Q}$ between the events has a mix of fast flash floods and a few spring rain-on-snow events with larger $T_{Q}$ and typically dry soils with a few exceptions. Dry soils, apparently, tend to enhance the variability of $T_{Q}$ and the opposite is the case in the wettest catchments (Brewa). Data analyses of Merz et al. [2006] suggest that the average runoff coefficient of flash floods in Austria is only 0.15 while other flood types have much larger runoff coefficients. In the high alpine catchments 
Table 3. Median of the Flood Timescales $T_{Q}(\mathrm{~h})$ of Annual Maximum Floods Stratified by Season of Occurrence (Left) and Flood Types (Right) ${ }^{\mathrm{a}}$

\begin{tabular}{|c|c|c|c|c|c|c|c|c|c|c|}
\hline Hours & $\begin{array}{l}\text { Winter } \\
\text { (DJF) }\end{array}$ & $\begin{array}{c}\text { Spring } \\
\text { (MAM) }\end{array}$ & $\begin{array}{l}\text { Summer } \\
\text { (JJA) }\end{array}$ & $\begin{array}{l}\text { Autumn } \\
\text { (SON) }\end{array}$ & Hours & $\begin{array}{c}\text { Long-Rain } \\
\text { Floor }\end{array}$ & $\begin{array}{c}\text { Short-Rain } \\
\text { flood }\end{array}$ & $\begin{array}{l}\text { Flash } \\
\text { Flood }\end{array}$ & $\begin{array}{c}\text { Rain-on-Snow } \\
\text { Flood }\end{array}$ & $\begin{array}{l}\text { Snowmelt } \\
\text { Flood }\end{array}$ \\
\hline 1 Buwe & 56.3 & 32.5 & 12.1 & 15.5 & 1 Buwe & 16.0 & 12.3 & 7.5 & 28.9 & 142.9 \\
\hline 2 Brewa & 18.9 & 23.7 & 16.6 & 17.6 & 2 Brewa & 17.0 & 15.4 & - & 19.1 & 30.8 \\
\hline 3 Flysch & 22.6 & 19.5 & 13.4 & 16.5 & 3 Flysch & 16.0 & 16.8 & 8.8 & 23.0 & - \\
\hline 4 Hoalp & 4.4 & 29.5 & 18.8 & 13.7 & 4 Hoalp & 16.6 & 19.3 & 11.4 & 40.0 & 57.2 \\
\hline 5 Weinv & 36.7 & 20.7 & 12.5 & 21.4 & 5 Weinv & 22.9 & 16.2 & 9.7 & 30.5 & 37.5 \\
\hline 6 Innv & 26.3 & 30.1 & 20.8 & 20.0 & 6 Innv & 25.0 & 23.5 & - & 27.2 & 17.4 \\
\hline 8 Mühlv & 39.8 & 55.9 & 34.6 & 38.1 & 8 Mühlv & 36.3 & 35.0 & - & 44.6 & - \\
\hline 9 Gail & 41.1 & 44.6 & 49.6 & 44.6 & 9 Gail & 40.3 & 47.2 & - & 58.6 & - \\
\hline 10 Dachst & 49.0 & 61.4 & 45.7 & 38.0 & 10 Dachst & 45.1 & 46.8 & - & 53.7 & 137.5 \\
\hline 11 Waldv & 47.3 & 74.8 & 38.8 & 29.4 & 11 Waldv & 41.9 & 42.4 & 18.1 & 65.3 & 159.3 \\
\hline 12 Gurk & 73.2 & 113.0 & 57.6 & 81.6 & 12 Gurk & 92.1 & 54.6 & 41.1 & 84.0 & 196.0 \\
\hline 13 Leitha & 95.9 & 117.3 & 103.2 & 125.4 & 13 Leitha & 98.4 & 89.7 & - & 117.7 & - \\
\hline
\end{tabular}

${ }^{\mathrm{a} D J F}$, December-January-February; MAM, March-April-May; JJA, June-July-August; SON, September-October-November.

(Hoalp, Ötzt) the $T_{Q}$ do not vary much between events and between catchments, as the maximum annual floods are mainly produced by synoptic storms where rainfall distribution is more uniform than for convective events. The catchments in the two hot spots contain both fast response areas (bare rocks) and delayed areas (debris) [M. Rogger, H. Pirkl, A. Viglione, J. Komma, R. Kirnbauer, R. Merz, and G. Blöschl, Step changes in the flood frequency curveprocess controls, submitted to Water Resource Research, 2011]. The Weinv hot spot is interesting as the rather small $\tilde{T}_{Q}$ is due to many convective events, but there are also synoptic and rain-on-snow events producing a mix of processes, which leads to a large variability and skew of $T_{Q}$. The catchments with many rain-on-snow events (Innv, Mühlv) tend to have wet antecedent soil moisture, which may lead to deeper flow paths and hence more delayed runoff. Merz et al. [2006] pointed out that the runoff coefficients of rain-on-snow events are on average 0.48 , which is significantly higher than those of rain-induced floods. Also, rain-on-snow events may last over a few days thereby additionally increasing $T_{Q}$.

[37] Although the tributaries to the Gail are very steep the $T_{Q}$ are not very fast because of the elongated shape of the catchment. In addition, debris on the hillslopes may

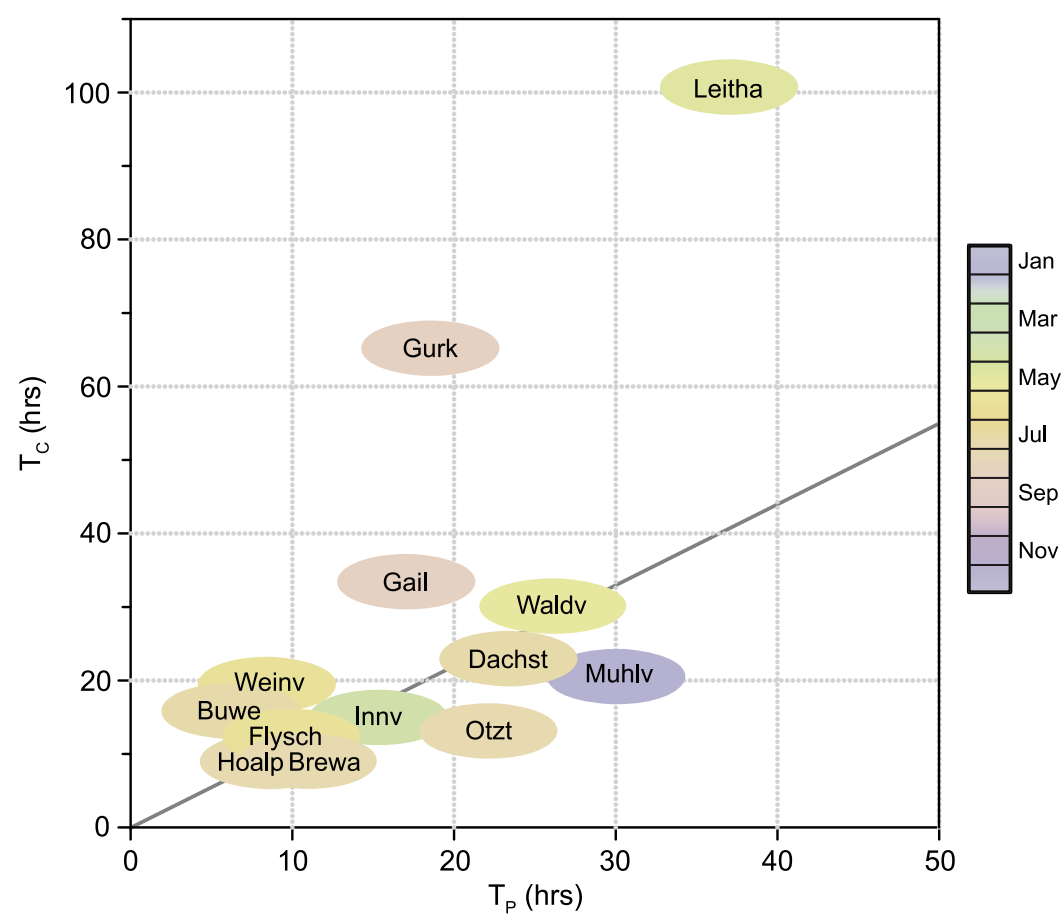

Figure 11. Summary of the catchment response timescale $T_{C}$ plotted against the median precipitation timescales $\tilde{T}_{P}$ of the maximum annual floods in the hot spot areas in Austria. Colors indicate mean month of flood occurrence. 
Table 4. Interplay of Climate and Catchment Processes in Controlling Flood Timescales $\tilde{T}_{Q}{ }^{\mathrm{a}}$

\begin{tabular}{|c|c|c|c|}
\hline Hot Spot & Climate Processes & Hot Spot & Catchment Processes \\
\hline \multirow[t]{2}{*}{ Buwe } & $\begin{array}{l}\text { Small } \tilde{T}_{Q} \text { due to convective storms, mostly in summer, flashy } \\
\text { shape partly due to partial storm coverage. }\end{array}$ & \multirow[t]{2}{*}{ Buwe } & Small $\tilde{T}_{Q}$ due to shallow soils and efficient drainage. \\
\hline & $\begin{array}{l}\text { Hot spot with the largest variability (and skew) of } T_{Q} \text { between } \\
\text { events due to fast flash floods and a few spring rain-on-snow } \\
\text { events with larger } T_{Q} \text {. }\end{array}$ & & $\begin{array}{l}\text { Large variability of } T_{Q} \text { between events partly associated with } \\
\text { rather dry soils but some events may have high antecedent soil } \\
\text { moisture with larger } T_{Q} \text {. }\end{array}$ \\
\hline Brewa & $\begin{array}{l}\text { Rather small } \tilde{T}_{Q} \text { due to convective and orographic storms } \\
\text { (imbedded), mostly in summer but some autumn events. }\end{array}$ & Brewa & $\begin{array}{l}\text { Rather small } \tilde{T}_{Q} \text { due to shallow soils. } \\
\text { Similar CDFs in all seasons and less skew than Buwe due to } \\
\text { persistently high soil moisture (as a result of high mean annual } \\
\text { precipitation). }\end{array}$ \\
\hline Flysch & $\begin{array}{l}\text { Rather small } \tilde{T}_{Q} \text { due to convective and orographic storms } \\
\text { (imbedded). Between Buwe and Brewa in terms of CDFs. } \\
\text { Mainly summer but also some spring and winter events which } \\
\text { are mostly rain-on-snow with longer } T_{O} \text {. }\end{array}$ & Flysch & $\begin{array}{l}\text { Rather small } \widetilde{T}_{Q} \text { due to shallow soils. } \\
\text { Spring and winter floods are a little longer due to higher } \\
\text { antecedent soil moisture. }\end{array}$ \\
\hline Hoalp & $\begin{array}{l}\text { Consistent } T_{Q} \text { (both between events and between catchments) } \\
\text { as floods are mainly due to synoptic storms. Almost all events } \\
\text { are in summer due to high elevations. }\end{array}$ & Hoalp & $\begin{array}{l}\text { Catchments contain both fast response areas (bare rocks) and } \\
\text { delayed areas (debris). }\end{array}$ \\
\hline Weinv & $\begin{array}{l}\text { Rather small } \tilde{T}_{Q} \text { due to many convective events. } \\
\text { Large variability (and skew) of } T_{Q} \text { between events due to a mix } \\
\text { of processes throughout the year (mostly convective, some } \\
\text { synoptic, some rain-on-snow events). }\end{array}$ & Weinv & Rather small $\tilde{T}_{Q}$ due to shallow soils. \\
\hline Innv & $\begin{array}{l}\text { Small variability of } T_{Q} \text { between flood types due to many rain- } \\
\text { on-snow events in winter, no flash floods. }\end{array}$ & Innv & $\begin{array}{l}\text { Rather flat and hilly terrain. } \\
\text { High antecedent soil moisture of rain-on-snow events. }\end{array}$ \\
\hline Ötzt & $\begin{array}{l}\text { Larger } \tilde{T}_{Q} \text { due to long synoptic storms in summer similar to } \\
\text { Hoalp but a number of rain-on-snow events with longer } T_{Q} \text {, } \\
\text { so } T_{Q} \text { is more skewed. }\end{array}$ & Ötzt & $\begin{array}{l}\text { Catchments contain both fast response areas (bare rocks) and } \\
\text { delayed areas (debris). }\end{array}$ \\
\hline Mühlv & $\begin{array}{l}\text { Rather large } \tilde{T}_{Q} \text { due to many rain-on-snow events in winter } \\
\text { similar to Innv. Small variability of } T_{Q} \text { between flood types. }\end{array}$ & Mühlv & Rather large $\tilde{T}_{Q}$ contributed to by sandy soils. \\
\hline Gail & $\begin{array}{l}\text { Rather large } \tilde{T}_{Q} \text { due to synoptic storms in summer and autumn. } \\
\text { Some rain-on-snow floods with somewhat longer } T_{O} \text {. }\end{array}$ & Gail & $\begin{array}{l}T_{Q} \text { not very fast, although rocks are steep because of elongated } \\
\text { shape of the catchment, debris may delay response. }\end{array}$ \\
\hline Dachst & $\begin{array}{l}\text { Rather large } \tilde{T}_{Q} \text { due to mostly synoptic storms in summer and } \\
\text { some snow events. }\end{array}$ & Dachst & $\begin{array}{l}\text { Rather large } \tilde{T}_{Q} \text { due to Karst processes. } \\
\text { Small } T_{Q} \text { never occur }\left(T_{Q} \text { always }>20 \mathrm{~h}\right) \text {. } \\
\text { Smooth shape of hydrographs indicates large subsurface or } \\
\text { near-surface component of stormflow. }\end{array}$ \\
\hline Waldv & $\begin{array}{l}\text { Rather large } \tilde{T}_{Q} \text { due to synoptic storms and rain-on-snow } \\
\text { events (with even larger } T_{Q} \text { ). }\end{array}$ & Waldv & $\begin{array}{l}\text { Rather large } \tilde{T}_{Q} \text { contributed to by sandy soils. } \\
\text { Because of sandy soils convective events less important. } \\
\text { Rather large } \tilde{T}_{Q} \text { contributed to by high antecedent soil moisture } \\
\text { of rain-on-snow events (deeper flow paths). }\end{array}$ \\
\hline Gurk & Mainly synoptic events, some rain-on-snow events & Gurk & $\begin{array}{l}\text { Very large } \tilde{T}_{Q} \text { due to large subsurface contribution to stormflow } \\
\text { as a result of highly permeable rock (weathered phyllites). Also } \\
\text { indicated by smooth hydrograph shapes. } \\
\text { Very large } \tilde{T}_{Q} \text { also contributed to by tortuous flow paths } \\
\text { (complex topography) related to rock type. }\end{array}$ \\
\hline Leitha & Mix of storm types around the year including rain-on-snow & Leitha & $\begin{array}{l}\text { Very large } \tilde{T}_{Q} \text { due to flood plain inundations in the lower } \\
\text { reaches. } \\
\text { Inundations also account for increase in } T_{Q} \text { with area (Figure 7). } \\
\text { Stream-aquifer interactions may contribute to delay. }\end{array}$ \\
\hline
\end{tabular}

${ }^{\mathrm{a}} \tilde{T}_{Q}$ is the median of the flood timescale $T_{Q}$.

delay the response. In the Dachst catchments, the smooth shape of hydrograph points to the important role of the subsurface or near-surface component of stormflow. Dachst is a karstic area, so one would expect a larger subsurface contribution to floods. Small $T_{Q}$ never occur in these catchments $\left(T_{Q}\right.$ are always $\left.>20 \mathrm{~h}\right)$. The Waldv catchments have rather delayed responses due to sandy soils as a result of the weathering of the granitic bedrock, so convective storms do not usually lead to maximum annual floods [see Viglione et al., 2010a, 2010b]. During rain-on-snow events in spring the high-antecedent soil moisture causes deeper flow paths to be activated [Komma et al., 2007], thus contributing to the rather large $T_{Q}$.

[38] The very large $T_{Q}\left(\tilde{T}_{Q}\right.$ of $\left.84 \mathrm{~h}\right)$ in the Gurk are due to large subsurface contributions to stormflow as a result of the highly permeable rock (weathered phyllites). The very large $T_{Q}$ are also contributed to by tortuous flow paths in the landscape. The complex topography is a result of the rock type and tectonic processes. In the Gurk, all flood types produce large $T_{Q}$, so catchment delay is the main driver of long $T_{Q}$. Finally, in the Leitha catchments there is a mix of storm types year round including rain-on-snow events. The very large $T_{Q}\left(\tilde{T}_{Q}\right.$ of $\left.104 \mathrm{~h}\right)$ are due to floodplain inundations in the flatlands of the lower reaches. The inundations also account for the increase in $T_{Q}$ with the area within the hot spot (Figure 6). The Leitha passes through sandy aquifers of the Südliches Wiener Becken where stream aquifer interactions may also contribute to the delayed response. In the Leitha hot spot, all flood types produce large $T_{Q}$, so catchment delay is the main driver of long $T_{Q}$, similar to Gurk, although the processes are different.

\subsection{Interplay of Processes and Scales}

[39] One of the strengths of comparative hydrology is that it allows the examination of processes in a more 

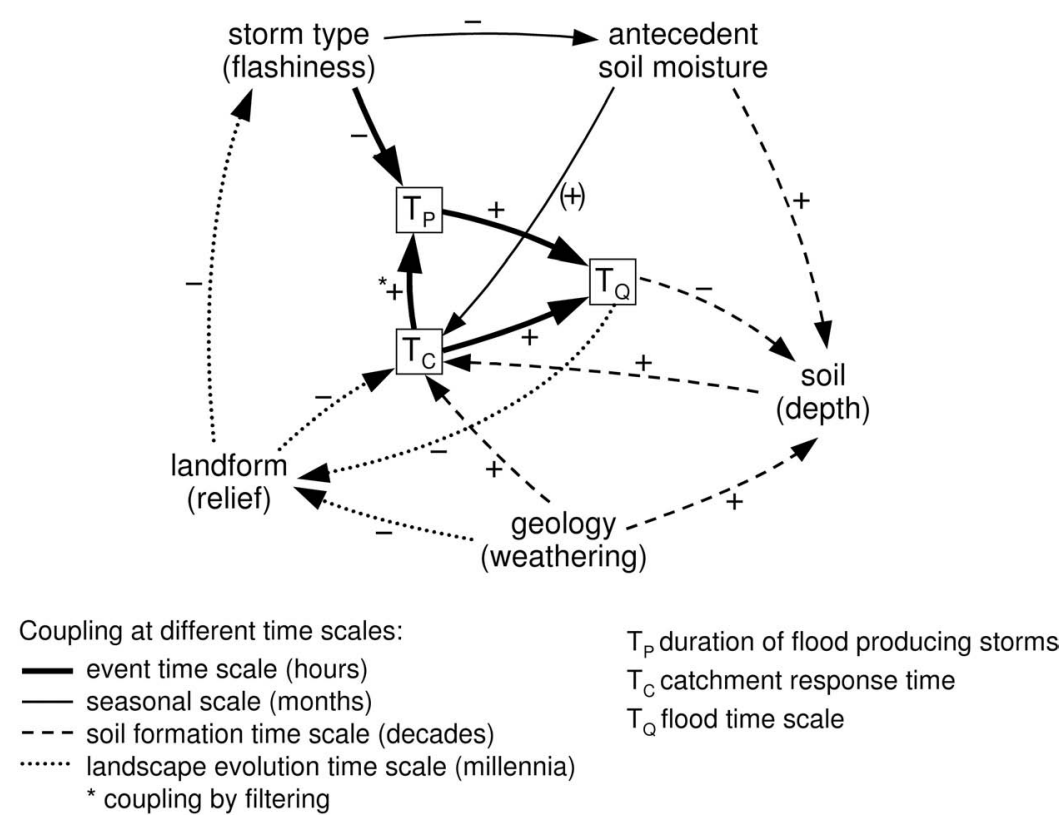

Figure 12. Schematic of the coupling of process controls on the flood timescale based on the comparative analyses of this study. Plus and minus signs indicate whether coupling is positive or negative, i.e., whether an increase in a variable increases or decreases another variable.

holistic way than does modeling. In a model only those processes and scales actually represented in the model can be analyzed, while in the comparative hydrology approach we can see the summary effect and interplay of all relevant processes if the data from the catchments of contrasting characteristics are compared. Based on the comparative analyses above it appears that climate and catchment processes affect the flood timescale $T_{Q}$ on at least four timescales (Figure 12). They are illustrated below on the basis of the hot spot data.

\subsubsection{Event Timescale (h)}

[40] As one example, in the Brewa hot spot, the maximum annual floods are due to short storms (median precipitation timescale $\tilde{T}_{P}=10 \mathrm{~h}$ ) and the catchment response is fast $\left(T_{C}=9 \mathrm{~h}\right)$; while in the Dachst region the maximum annual floods are due to longer synoptic storms $\left(\tilde{T}_{P}=23\right.$ $\mathrm{h})$ and the catchment response is also much more delayed $\left(T_{C}=22 \mathrm{~h}\right)$ as a result of the Karst. Much shorter and much longer storms than the catchment response time do occur in both catchments but they are not typically those that produce the maximum annual floods. This is because the catchment response timescales filter the distribution of all storms to produce the distribution of flood producing storms [Viglione and Blöschl, 2009]. $\tilde{T}_{P}$ and $T_{C}$, therefore, tend to cluster around the $1: 1$ line in Figure 11. This filtering (indicated as an asterisk in Figure 12) is also the reasoning of the rational method argument.

\subsubsection{Seasonal Scale (Months)}

[41] In the Buwe hot spot (mean annual precipitation $\sim 850 \mathrm{~mm}$ ) there is a large variability of flood timescales between events $(\mathrm{CV}=1.14$, Table 1$)$, which is partly associated with generally dry soils but some events may have high-antecedent soil moisture with larger $T_{Q}$. In contrast, the Brewa hot spot has very little variation of the flood timescales between seasons $(\mathrm{CV}=0.46$, Table 1$)$, which is related to the persistently high soil moisture as a result of the high mean annual precipitation $(2000 \mathrm{~mm})$. In humid climates, flood characteristics tend to be closely related to the seasonal water balance [Sivapalan et al., 2005]. Conversely, the runoff event types affect the seasonal water balance through rainfall and snowmelt.

\subsubsection{Soil Formation Timescale (Decades)}

[42] The Waldv hot spots have sandy, high-permeability soils which result in deep flow paths and therefore relative long flood response times $\left(T_{Q}=50 \mathrm{~h}\right)$. Event water storage can be $60 \mathrm{~mm}$ [Komma et al., 2007]. There is little overland flow [Viglione et al., 2010a, 2010b; Blöschl et al., 2008] which produces little erosion. In contrast, the Flysch catchments have relatively shallow soils and therefore much faster flood response $\left(T_{Q}=18 \mathrm{~h}\right)$, which in turn tends to enhance erosion. Soil depth and permeability affect flow paths and therefore flood response. In turn, the flow paths as well as soil moisture affect erosion during floods and soil evolution. These processes are modulated by differences in geology (granite in the Waldv and Flysh in the Flysch hot spots).

\subsubsection{Landscape Evolution Timescale (Millennia)}

[43] The Gurk catchments have flood timescales of almost $100 \mathrm{~h}$ while the Buwe catchments have flood timescales $\sim 16 \mathrm{~h}$. Clearly, the main difference is due to the different geologies. The Gurk phyllites are deeply weathered leading to deep soils and therefore deep flow paths, while the marl and clay geology in the Buwe leads to shallower soils and faster flow paths. However, there is an interplay of the flood event scale with landscape evolution. Figure 13 suggests that the differences in the timescales of the two 

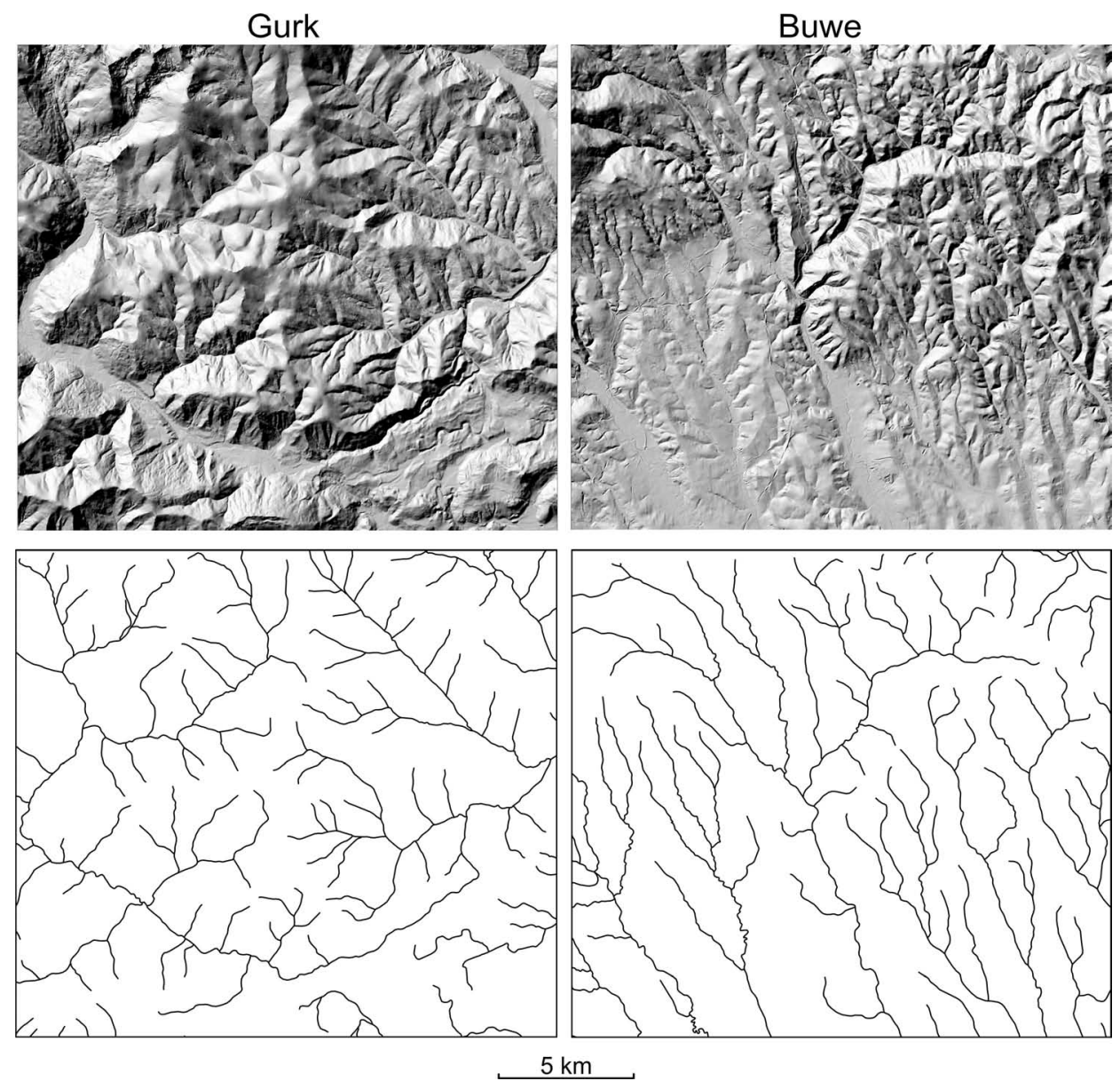

Figure 13. Topography (top) and stream network (1:50,000 resolution) (bottom) for the Gurk (left) and the Buwe (right) hot spots. Note the tortuous drainage network of the Gurk and the efficient drainage network in the Buwe. The different drainage networks have evolved as a result of an interplay of catchment and climate processes at the landscape evolution timescale, modulated by geology.

hot spots are not only due to geology, they are also due to geomorphology. The Gurk has very tortuous flow paths both on the hillslopes and in the valleys. In contrast, the landscape of the Buwe catchments has produced an efficient drainage network as a result of erosive action due to the fast flood response. In the Buwe one would expect a more efficient drainage network to develop as a result of higher overland flow intensities [Abrahams and Ponczynski, 1984; Tucker and Bras, 2000]. This means there is an interplay at the landscape evolution timescale. In the Buwe, the catchment form has adapted to the flashy floods and produced an efficient drainage network which in turn enhances the flashiness of the flood response. In the Gurk, a tortuous drainage network has evolved, which in turn retards flood response and impedes the evolution of an efficient drainage network. This is an example of the coevolution of landform and hydrological processes discussed by Harvey [2002], Sivapalan [2005], Kirkby [2005], Jefferson et al. [2010], and Wagener et al. [2010]. Blöschl and Merz [2010] suggest that, when moving from low rainfall to high rainfall catchments, flood runoff increases more than does rainfall because of the enhanced effect of erosion at the flood event scale on landform evolution at the long-term scale. This can involve threshold processes which may further enhance the interplay of the controls [Zehe et al., 2007].

\subsection{Implications for Hydrological Modeling}

\subsubsection{Process Controls and Modeling}

[44] The comparative analyses in this paper have indicated that the flood timescales are indeed controlled by a number of interacting factors. In the humid climate of the study region of this paper it is clear that, over the catchment scales examined here (tens to hundreds of $\mathrm{km}^{2}$ ) the flood timescales do not depend much on the catchment area. Other controls are much more important. Lag time equations that are based on catchment area and root of slope do not account for differences in soils, geology, and climate. They therefore do not represent differences in the flood-generating processes and will not capture important differences in flood response across the landscape. More generally speaking, catchment models that are purely topographically driven are not applicable in this context and the climatic and soil/geologic controls matter more than topography per se. Similarly, it will not always be appropriate to extrapolate plot scale hydraulic equations of flood response times to the catchment 
scale. This may be justifiable in small urban catchments and in arid climates where overland flow dominates (provided one can assume the plot scale landform and roughness is the same in the entire catchment). However, for other catchment conditions (e.g., in rural humid catchments or mountainous catchments) other factors may be much more important that are related to catchment processes (including soils and landscape evolution) and climate processes (including snowmelt and rain-on-snow). There is considerable potential for exploiting these findings in the context of flood frequency hydrology [Merz and Blöschl, 2008].

\subsubsection{Value of Comparative Hydrology}

[45] Differences in the response characteristics between hot spots have proven to be very useful for understanding flood processes at the catchment scale. These include climate drivers and catchment drivers. The climate drivers, such as the storm type (synoptic and convective storms, snowmelt, and rain-on-snow), shed light on the nature of the climate input to the floods. Timing within the year as well as hydrograph shape (flashiness and daily fluctuations) provide information on the type of input. The catchment drivers include soil moisture, hillslope flow paths, and routing processes in the landscape. Of particular value has been the comparison of catchments that differ in climate and geology. Again, the hydrograph shape tells us something about process, e.g., a smooth hydrograph shape points to a large subsurface component in the runoff hydrograph. These comparisons allowed us to shed light on process interactions and feedbacks across timescales that are not easy to capture by hydrological modeling, such as the evolution of an efficient drainage systems in catchments where flashy floods are common. The integrated nature of the comparison of the data from contrasting hot spots allowed us to identify the relative role of processes, feedbacks, and interactions that would be difficult to obtain from complex models. Engineering hydrology has typically only considered the event-based effects (thick lines in Figure 12), while the comparative hydrology approach allows us to consider a wider spectrum of processes and scales. This is in line with what Sivapalan [2005, p. 212] terms the new paradigms of hydrological science that involves "holistic descriptions, process interactions and feedbacks, data as a source of learning, heterogeneity as a window into catchment functioning," and may be a stepping stone toward synthesis in hydrology [Kovács, 1984; Blöschl, 2006].

\subsubsection{Similarity Measures}

[46] The flood timescale used here, and the comparative analyses, also lends themselves for defining hydrological similarity as is needed for predictions in ungauged catchments. The flood timescale is a rich fingerprint of the hydrological processes in a catchment because it integrates a range of climate and catchment characteristics by a time parameter. The flood timescales are a measure of dynamic processes in the catchment, i.e., related to time rather than length as are other similarity measures commonly used in hydrology (catchment area, wetness index, etc.). As Patil and Stieglitz [2011] noted, the similarity between catchments is not necessarily a stationary quantity that is preserved across diverse flood-generating conditions. It is not always clear how similarities among catchments are created and preserved across diverse conditions and yet they could be helpful in relating hillslope and catchment complexity [Sivapalan, 2003]. The flood timescales examined here, indeed differ between events (rain floods, snowmelt, rain-on-snow floods) and between catchments due to differences in both climate and catchment characteristics. A global catalogue of catchment types, in terms of flow paths, runoff mechanisms, and hydrological regimes would be of great value. The flood timescale may be a useful index for organizing flood response to bring order into the seemingly unrelated facts reported on floods around the world.

\section{Appendix A: Relationship Between the Median Flood Timescales and the Selected Catchment Attributes}

[47] The univariate and bivariate Pearson correlation coefficients between the median flood timescales $\tilde{T}_{Q}$ and the selected catchment attributes are shown in Table A1.

Table A1. Bivariate Correlations (Adjusted Pearson's $R^{2}$ in Percent) of Median Flood Timescales $\tilde{T}_{Q}$ and Two Catchment Attributes ${ }^{\mathrm{a}}$

\begin{tabular}{|c|c|c|c|c|c|c|c|c|c|c|c|}
\hline & Univariate & $\begin{array}{l}\text { Log } \\
\text { Area }\end{array}$ & RND & MAP & Slope & Podsol & Tertiary & $\begin{array}{c}\text { Flysch, } \\
\text { Marl }\end{array}$ & $\begin{array}{c}\text { Phyllite, } \\
\text { Schist }\end{array}$ & Crop Land & $\begin{array}{c}\text { Forest } \\
\text { (Conif.) }\end{array}$ \\
\hline Univariate & - & $20^{+}$ & $4^{-}$ & $2^{-}$ & $3^{+}$ & $7^{+}$ & $10^{-}$ & $4^{-}$ & $5^{+}$ & $2^{-}$ & $15^{+}$ \\
\hline RND & $4^{-}$ & 24 & - & 7 & 5 & 11 & 11 & 7 & 10 & 7 & 21 \\
\hline MAP & $2^{-}$ & 20 & 7 & - & 10 & 8 & 16 & 5 & 6 & 6 & 16 \\
\hline Slope & $3^{+}$ & 21 & 5 & 10 & - & 9 & 9 & 6 & 6 & 4 & 17 \\
\hline Podsol & $7^{+}$ & 25 & 11 & 8 & 9 & - & 13 & 12 & 11 & 8 & 18 \\
\hline Tertiary & $10^{-}$ & 26 & 11 & 16 & 9 & 13 & - & 14 & 12 & 9 & 19 \\
\hline Flysch, marl & $4^{-}$ & 22 & 7 & 5 & 6 & 12 & 14 & - & 8 & 6 & 16 \\
\hline Phyllite, schist & $5^{+}$ & 22 & 10 & 6 & 6 & 11 & 12 & 8 & - & 6 & 17 \\
\hline Crop land & $2^{-}$ & 22 & 7 & 6 & 4 & 8 & 9 & 6 & 6 & - & 15 \\
\hline Forest (conif.) & $15^{+}$ & 28 & 21 & 16 & 17 & 18 & 19 & 16 & 17 & 15 & - \\
\hline
\end{tabular}

${ }^{a}$ Correlations that are significant at the $95 \%$ level are printed in bold. For the univariate correlations the sign of the correlation coefficient $R$ is indicated. Catchment attributes: $\log$ area: $\log$ of the catchment area $\left(\mathrm{km}^{2}\right)$; RND: river network density (-); MAP: mean annual precipitation (mm); slope: mean topographic slope [-]; Podsol: percent of Podsol soil type; tertiary: percent of tertiary geology; flysch, marl: percent of flysch and marl geology; phyllite, schist: percent of phyllite and schist geology; crop land: percent of crop land; forest (conif.): percent of coniferous forest in the catchment area. For details of the attributes see Merz and Blöschl [2009b]. 


\section{Appendix B: A Procedure for Identifying the Hot Spot Areas in Austria}

[48] The hot spots are regions where the flood generating mechanisms are considered rather uniform within the region but different from other regions. The following protocol was adhered in identifying the hot spots:

[49] Synoptic maps were produced of the study region showing the stream network, geology, topography and extreme rainfall (Figure 1), and mean annual precipitation [Blöschl and Merz, 2010].

[50] Synoptic maps were produced with the specific mean annual flood discharge [Merz and Blöschl, 2009b] and the median flood timescale (Figure 4) indicated for each stream gauge.

[51] The mean annual flood was also regionalized for the entire study region for more detailed spatial coverage [Skøien et al., 2006].

[52] Clusters of stream gauges with particularly small median flood timescales were identified from the maps. The clusters had to be spatially contiguous and both nested and non-nested catchments were allowed in a cluster. Individual, isolated stream gauges with small flood timescales were not considered as clusters.

[53] These clusters were then interpreted in terms of the hydrological processes based on the synoptic maps as well as on other hydrological information available in the area on floods [Merz and Blöschl, 2003], runoff coefficients [Merz and Blöschl, 2009a], snow [Parajka and Blöschl, 2008], soil moisture [Parajka et al., 2005], and low flow processes [Laaha and Blöschl, 2006]. Going beyond flood hydrology allowed for a more holistic assessment of catchment response.
[54] From the visual assessment it was clear that both climate and hydrogeology play a key role for the magnitude of the median flood timescales because of the colocation of geologic units and climate regions with the catchments exhibiting small flood timescales. On the basis of the hydrological interpretation, hot spots were delineated with the condition of a minimum of four and a maximum of seven stream gauges.

[55] This delineation resulted in five hot spots with rather small flood timescales satisfying the requirement that the catchments within a given hot spot were similar from a hydrologic perspective. These were Buwe, Brewa, Flysch, Hoalp, and Weinv (Table B1).

[56] In a next step, clusters of stream gauges with particularly large median flood timescales were identified from the maps. A similar procedure was adhered to.

[57] This resulted in five hot spots with rather large flood timescales. These were Gail, Dachst, Waldv, Gurk, and Leitha (Table B1).

[58] Next, the seasonality of flood processes in Austria was analyzed [see Merz and Blöschl, 2003]. In northwestern Austria, floods tend to occur in winter and early spring which is different from the flood occurrence in late spring, summer, and autumn in the rest of the study region. To capture this characteristic flood behavior, two additional hot spots were introduced: Innv and Mühlv (Table B1).

[59] Finally, a hot spot was introduced to represent the flooding in the mountainous catchments of Tyrol. This was Ötzt (Table B1).

[60] This procedure led to a total of 13 hot spots with contrasting flood characteristics. The advantage of this identification of the hot spots over more formal procedures such as cluster analysis is that the hydrological interpretation was directly considered in the selection of the hot spots.

Table B1. Composition of the Hot Spots and Detailed Information on the Catchments Involved ${ }^{\text {a }}$

\begin{tabular}{|c|c|c|c|c|c|c|c|c|}
\hline Location & Region & Geology & Stream Gauge/Stream & $\begin{array}{l}\text { Catchment } \\
\text { Area }\left(\mathrm{km}^{2}\right)\end{array}$ & $\begin{array}{l}\text { Elevation } \\
\text { (m.a.s.l) }\end{array}$ & $\begin{array}{c}\text { Mean } \\
\text { Annual } \\
\text { Precipitation }(\mathrm{mm})\end{array}$ & $\begin{array}{c}\text { Annual } \\
\text { Maximum } \\
\text { Flood Events }\end{array}$ & $\tilde{T}_{Q}$ \\
\hline \multirow[t]{7}{*}{1} & \multirow{7}{*}{$\begin{array}{l}\text { Bucklige Welt } \\
\text { (Buwe) }\end{array}$} & \multirow{7}{*}{ Marl, clay } & Arzberg (Moderbach)/Moderbach & 84 & 824 & 882 & 15 & 17.9 \\
\hline & & & Altschlaining/Tauchenbach & 89 & 508 & 760 & 21 & 18.0 \\
\hline & & & Kirchschlag in der Buckl.Welt/Zöbernbach & 114 & 585 & 835 & 14 & 8.5 \\
\hline & & & Feistritz am Wechsel/Feistritz & 114 & 852 & 984 & 14 & 13.0 \\
\hline & & & Mitterdorf an der Raab/Raab & 184 & 749 & 878 & 15 & 16.4 \\
\hline & & & Warth/Pitten & 277 & 756 & 962 & 14 & 14.9 \\
\hline & & & Hammerkastell/Lafnitz & 286 & 813 & 906 & 14 & 15.3 \\
\hline \multirow[t]{6}{*}{2} & \multirow{6}{*}{$\begin{array}{l}\text { Bregenzwald } \\
\text { (Brewa) }\end{array}$} & \multirow[t]{6}{*}{ Flysh, marl } & Schwarzach/Schwarzach & 18 & 786 & 1966 & 21 & 18.0 \\
\hline & & & Schönenbach (Hengstig)/Subersach & 31 & 1449 & 1954 & 20 & 22.3 \\
\hline & & & Laterns/Frutz & 33 & 1475 & 2024 & 21 & 16.8 \\
\hline & & & Enz/Dornbirnerach & 51 & 1148 & 2112 & 18 & 13.0 \\
\hline & & & Lingenau/Subersach & 112 & 1197 & 2048 & 21 & 16.5 \\
\hline & & & Krumbach-Zwing/Weißach & 199 & 1103 & 2065 & 28 & 18.4 \\
\hline \multirow[t]{6}{*}{3} & \multirow{6}{*}{$\begin{array}{l}\text { Flysch } \\
\text { (Flysch) }\end{array}$} & \multirow[t]{6}{*}{ Flysh } & Unterkirchbach/Hagenbach & 6 & 366 & 753 & 20 & 13.5 \\
\hline & & & Schliefau/Schliefaubach & 18 & 607 & 1199 & 18 & 20.5 \\
\hline & & & Klosterneuburg (Prägarten)/Weidlingbach & 33 & 337 & 750 & 18 & 19.7 \\
\hline & & & Böheimkirchen/Perschling & 55 & 333 & 764 & 22 & 20.1 \\
\hline & & & Lachau/Melk & 95 & 347 & 862 & 25 & 13.9 \\
\hline & & & Krenstetten/Urlbach & 156 & 389 & 994 & 28 & 21.8 \\
\hline \multirow[t]{4}{*}{4} & \multirow{4}{*}{$\begin{array}{l}\text { Hochalpen } \\
\text { (Hoalp) }\end{array}$} & \multirow{4}{*}{$\begin{array}{l}\text { Granite, Carbonate, } \\
\text { Phyllite }\end{array}$} & Innergschlöß/Gschlößbach & 39 & 2577 & 1120 & 19 & 18.8 \\
\hline & & & Böckstein/Naßfelder Bach & 57 & 2143 & 1398 & 20 & 16.2 \\
\hline & & & Matreier Tauernhaus/Tauernbach & 61 & 2475 & 1143 & 23 & 18.9 \\
\hline & & & Bucheben/Hüttwinkelache & 96 & 1987 & 1310 & 24 & 17.7 \\
\hline \multirow[t]{5}{*}{5} & \multirow{5}{*}{$\begin{array}{l}\text { Weinviertel } \\
\text { (Weinv) }\end{array}$} & \multirow[t]{5}{*}{ Marl, clay } & Asparn an der Zaya/Zaya & 81 & 294 & 590 & 15 & 20.2 \\
\hline & & & Ulrichskirchen (Sportplatz)/Rußbach & 132 & 251 & 558 & 19 & 13.3 \\
\hline & & & Hollenstein/Schmida & 212 & 313 & 508 & 25 & 19.3 \\
\hline & & & Zwingendorf/Pulkau & 372 & 264 & 486 & 28 & 22.2 \\
\hline & & & Obermallebarn/Göllersbach & 380 & 270 & 507 & 23 & 19.3 \\
\hline
\end{tabular}


Table B1. (continued)

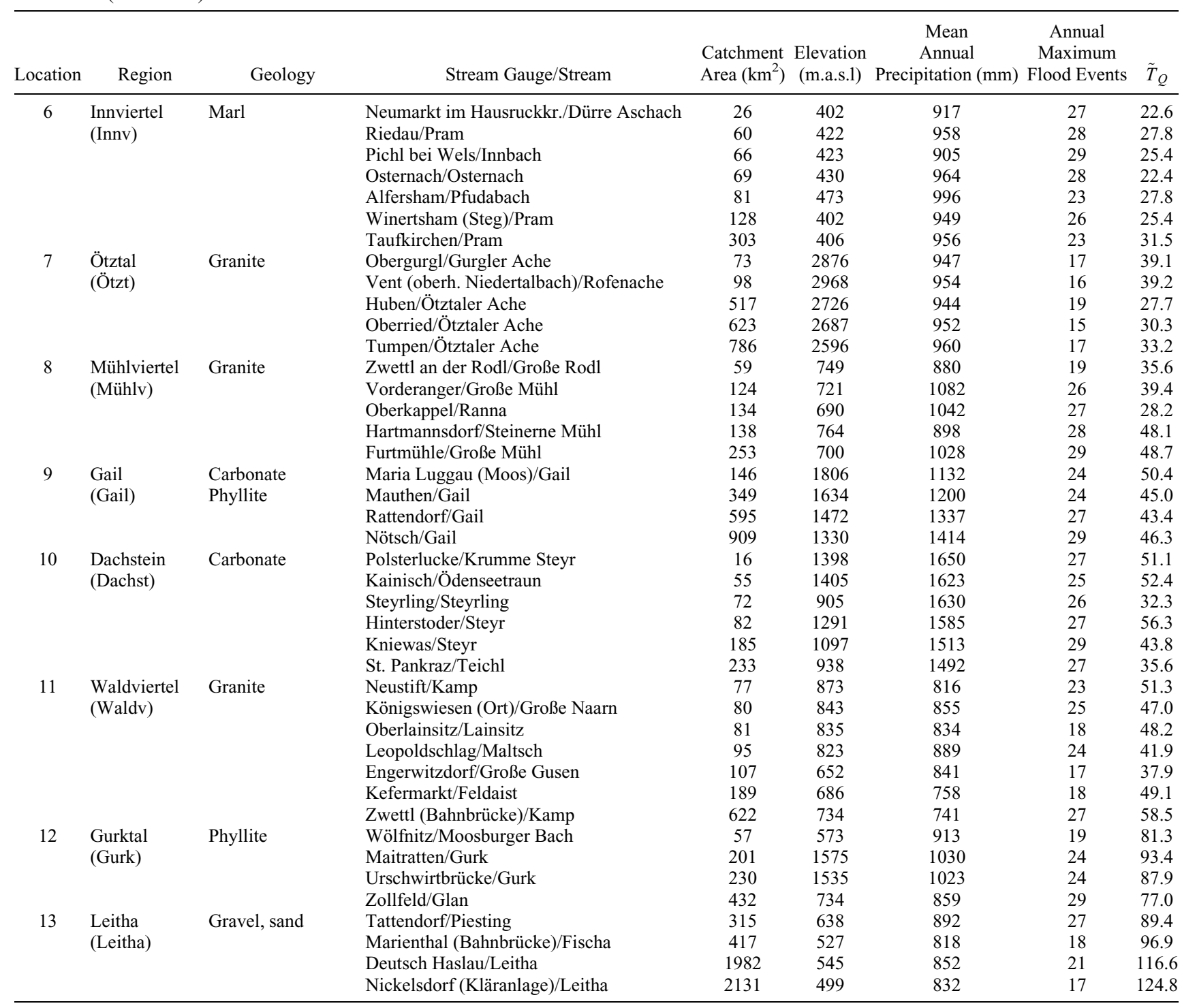

a Abbreviations: Elevation: mean catchment elevation; $\tilde{T}_{Q}:$ median of flood timescales.

[61] Acknowledgments. This study was supported by the Austrian Academy of Sciences (International Strategy for Disaster Reduction Programme, IWHRE2008, 2008-2011), the Slovak Research and Development Agency (contract APVV0496-10), and the Austrian Science Funds (project P23723-N21). The authors would also like to thank three anonymous reviewers and the editor for their useful comments and suggestions on the manuscript.

\section{References}

Abrahams, A. D., and J. J. Ponczynski (1984), Drainage density in relation to precipitation intensity in the USA, J. Hydrol., 75, 383-388.

Apel, H., A. H. Thieken, B. Merz, and G. Blöschl (2006), A probabilistic modelling system for assessing flood risks, Nat. Hazards, 38, 79-100, doi: 10.1007/s11069-005-8603-7.

Bell, F. C., and S. O. Kar (1969), Characteristic response times in design flood estimation, J. Hydrol., 8, 173-196.

Blöschl, G. (2006), Hydrologic synthesis-across processes, places and scales, Special section on the vision of the CUAHSI National Center for Hydrologic Synthesis (NCHS), Water Resour. Res., 42, W03S02, doi:10.1029/2005WR004319.

Blöschl, G., and R. Merz (2010), Landform-hydrology feedbacks, in Landform-Structure, Evolution, Process Control, Lecture Notes in Earth Sciences, 115, edited by J.-C. Otto and R. Dikau, pp. 117-126, Springer, Heidelberg, Germany.
Blöschl, G., C. Reszler, and J. Komma (2008), A spatially distributed flash flood forecasting model, Environ. Modell. Software, 23, 464-478, doi:10.1016/j.envsoft.2007.06.010.

Borah, D. K. (2011), Hydrologic procedures of storm event watershed models: A comprehensive review and comparison, Hydrol. Processes, 25,3472-3489, doi:10.1002/hyp.8075.

Chapman, T. G., and A. I. Maxwell (1996), Baseflow separation-comparison of numerical methods with tracer experiments, in 23rd Hydrology and Water Resources Symposium: Water and the Environment, Natl. Conf. Publ., 96/05, pp. 539-545, Inst. of Eng., Barton, A.C.T., Australia.

Corradini, C., F. Melone, and V. P. Singh (1995), Some remarks on the use of GIUH in the hydrological practice, Nord. Hydrol., 26, $297-312$.

Dooge, J. C. I. (2005), Bringing it all together, Hydrol. Earth Syst. Sci., 9 , 3-14, doi:10.5194/hess-9-3-2005.

Dunne, T. (1978), Field studies of hillslope flow processes, in Hillslope Hydrology, edited by M. J. Kirby, pp. 227-293, John Wiley, N. Y.

Falkenmark, M., and T. C. Chapman (1989), Comparative Hydrology: An Ecological Approach to Land and Water Resources, 479 pp., UNESCO, Paris, France.

Fang, X., T. Cleveland, C. A. Garcia, D. Thompson, and R. Malla (2005), Literature Review on Timing Parameters for Hydrographs, Rep. 0-4696-1, 73 pp., Dept. of Civil Engineering, College of Engineering, Lamar Univ., Beaumont, Tex. 
Folmar, N. D., A. C. Miller, and D. E. Woodward (2007), History and development of the NRCS lag time equation, J. Am. Water Resour. Assoc., 43(3), 829-838, doi:10.1111/j.1752-1688.2007.00066.x.

Harlina, J. M. (1984), Watershed morphometry and time to hydrograph peak, J. Hydrol., 67, 141-154.

Harvey, A. M. (2002), Effective timescales of coupling within fluvial systems, Geomorphology, 44, 175-201.

Hirschboeck, K. K., L. Ely, and R. A. Maddox (2000), Hydroclimatology of meteorologic floods, in Inland Flood Hazards: Human, Riparian and Aquatic Communities, edited by E. Wohl, pp. 39-72, Cambridge Univ. Press, N. Y.

Hood, M. J., J. C. Clausen, and G. S. Warner (2007), Comparison of stormwater lag times for low impact and traditional residential development, $J$. Am. Water Resour. Assoc., 43(4), 1036-1046, doi:10.1111/j.1752-1688. 2007.00085.x.

Jefferson, A., G. E. Grant, S. L. Lewis, and S. T. Lancaster (2010), Coevolution of hydrology and topography on a basalt landscape in the Oregon Cascade Range, USA, Earth Surf. Processes Landforms, 35, 803-816. doi:10.1002/esp. 1976 .

Karcz, I. (1972), Sedimentary structures formed by flash floods in southern Israel, Sediment. Geol., 7, 161-182.

Kirkby, M. (2005), Organisation and process, Article 4, in Encyclopedia of Hydrol. Sci., M. G. Anderson (Managing Editor), pp. 41-85, John Wiley, Chichester, U. K.

Kirpich, P. Z. (1940), Time of concentration of small agricultural watersheds, Civil Eng., 10(6), 362.

Klimešová, J. (1994), The effects of timing and duration of floods on growth of young plants of Phalaris arundinacea L. and Urtica dioica L.: An experimental study, Aquat. Bot., 48, 21-29.

Komma, J., C. Reszler, G. Blöschl, and T. Haiden (2007), Ensemble prediction of floods - catchment non-linearity and forecast probabilities, Nat. Hazards Earth Syst. Sci., 7, 431-444, doi:10.5194/nhess-7-4312007.

Kovács, G. (1984), Proposal to construct a coordinating matrix for comparative hydrology, Hydrolog. Sci. J., 29, 435-443.

Laaha, G., and G. Blöschl (2006), A comparison of low flow regionalisation methods - catchment grouping. J. Hydrol., 323, 193-214, doi:10.1016/ j.jhydrol.2005.09.001

Loukas, A., and M. C. Quick (1996), Physically-based estimation of lag time for forested mountainous watersheds, Hydrolog. Sci. J., 41, 1-19.

McCuen, R. H., S. L. Wong, and W. J. Rawls (1984), Estimating urban time of concentration, J. Hydraul. Eng., 110(7), 887-904.

McEnroe, B. M., and H. Zhao (1999), Lag Times and Peak Coefficients for Rural Watersheds in Kansas, K-TRAN Research Project KU-98-1, School of Engineering, Univ. of Kansas, Lawrence, Kans., 44 pp.

Melone, F., C. Corradini, and V. P. Singh (2002), Lag prediction in ungauged basins: An investigation through actual data of the upper Tiber River valley, Hydrol. Processes, 16, 1085-1094.

Merz, R., and G. Blöschl (2003), A process typology of regional floods, Water Resour. Res., 39(12), 1340, doi:10.1029/2002WR001952.

Merz, R., and G. Blöschl (2008), Flood frequency hydrology: 1. Temporal, spatial, and causal expansion of information, Water Resour. Res., 44(8), W08432, doi: 10.1029/2007WR006744.

Merz, R., and G. Blöschl (2009a), A regional analysis of event runoff coefficients with respect to climate and catchment characteristics in Austria, Water Resour. Res., 45, W01405, doi:10.1029/2008WR007163.

Merz, R., and G. Blöschl (2009b), Process controls on the statistical flood moments - a data based analysis, Hydrol. Processes, 23, 675-696, doi: $10.1002 /$ hyp 7168 .

Merz, R., G. Blöschl, and J. Parajka (2006), Spatio-temporal variability of event runoff coefficients in Austria, J. Hydrol., 331, 591-604, doi:10. 1016/j.jhydrol.2006.06.008.

Merz, R., J. Parajka, and G. Blöschl (2009), Scale effects in conceptual hydrological modeling, Water Resour. Res., 45, W09405, doi:10.1029/ 2009WR007872.

Parajka, J., and G. Blöschl (2008), Spatio-temporal combination of MODIS images-potential for snow cover mapping, Water Resour. Res., 44, W03406, doi:10.1029/2007WR006204.

Parajka, J., V. Naeimi, G. Blöschl, W. Wagner, R. Merz, and K. Scipal (2005), Assimilating scatterometer soil moisture data into conceptual hydrologic models at the regional scale, Hydrol. Earth Syst. Sci., 10, 353-368, doi:10.5194/hess-10-353-2006.

Parajka, J., et al. (2010), Seasonal characteristics of flood regimes across the Alpine-Carpathian range, J. Hydrol., 394(1-2), 78-89, doi:10.1016/ j.jhydrol.2010.05.015.
Patil, S., and M. Stieglitz (2011), Hydrologic similarity among catchments under variable flow conditions, Hydrol. Earth Syst. Sci., 15, 989-997, doi: 10.5194/hess-15-989-2011.

Rao, A. R., J. W. Delleur, and P. B. S. Sarama (1972), Conceptual hydrologic models for urbanizing basins, J. Hydraul. Eng., 98(HY7), 1205-1220.

Sefton, C. E. M., and S. M. Howarth (1998), Relationships between dynamic response characteristics and physical descriptors of catchments in England and Wales, J. Hydrol., 211, 1-16.

Sheridan, J. M. (1994), Hydrograph time parameters for flatland watersheds, T. ASABE, 37(1), 103-113.

Sivapalan, M. (2003), Process complexity at hillslope scale, process simplicity at the watershed scale: Is there a connection?, Hydrol. Processes 17, 1037-1041.

Sivapalan, M. (2005), Pattern, process and function: Elements of a unified theory of hydrology at the catchment scale, in Encyclopedia of Hydrol. Sci., edited by M. G. Anderson, pp. 193-219, John Wiley, London, U. K.

Sivapalan, M. (2009), The secret to "doing better hydrological science": Change the question! Hydrol. Processes, 23, 1391-1396, doi:10.1002/ hyp. 7242 .

Sivapalan, M., G. Blöschl, R. Merz, and D. Gutknecht (2005), Linking flood frequency to long-term water balance: Incorporating effects of seasonality, Water Resour. Res., 41, W06012, doi:10.1029/2004WR003439.

Skøien, J., and G. Blöschl (2006), Catchments as space-time filters-a joint spatio-temporal geostatistical analysis of runoff and precipitation, Hydrol. Earth Syst. Sci., 10, 645-662, doi:10.5194/hess-10-645-2006.

Skøien, J. O., G. Blöschl, and A. W. Western (2003), Characteristic space scales and timescales in hydrology, Water Resour. Res., 39(10), 1304, doi: 10.1029/2002WR001736.

Skøien, J., R. Merz, and G. Blöschl (2006), Top-kriging-geostatistics on stream networks, Hydrol. Earth Syst. Sci., 10, 277-287, doi:10.5194/ hess-10-277-2006.

Smithers, J. C. (2011), Opportunities for design flood estimation in South Africa, Proc. 15th SANCIAHS Symposium on Science and Practice for Sustainable Water Resour. Manage., 12 to 14 September 2011, Rhodes University, Grahamstown, South Africa, available at http://www. ru.ac.za/static/institutes/iwr/SANCIAHS/2011/the.pdffiles/JC_Smithers_ Paper.pdf.

Thieken, A. H., M. Müller, H. Kreibich, and B. Merz (2005), Flood damage and influencing factors: New insights from the August 2002 flood in Germany, Water Resour. Res., 41, W12430, doi:10.1029/2005WR004177.

Tucker, G., and R. Bras (2000), A stochastic approach to modeling the role of rainfall variability in drainage basin evolution, Water Resour. Res., 36(7), 1953-1964

Viglione, A., and G. Blöschl (2009), On the role of storm duration in the mapping of rainfall to flood return periods, Hydrol. Earth Syst. Sci., 13, 205-216, doi:10.5194/hess-13-205-2009.

Viglione, A., G. B. Chirico, J. Komma, R. Woods, M. Borga, and G. Blöschl (2010a), Quantifying space-time dynamics of flood event types, J. Hydrol., 394(1-2), 213-229, doi:10.1016/j.jhydrol.2010.05.041.

Viglione, A., G. B. Chirico, R. Woods, and G. Blöschl (2010b), Generalised synthesis of space-time variability in flood response: An analytical framework, J. Hydrol., 394(1-2), 198-212, doi:10.1016/j.jhydrol.2010.05.047.

Wagener, T., M. Sivapalan, P. A. Troch, B. L. McGlynn, C. J. Harman, H.

V. Gupta, P. Kumar, P. S. C. Rao, N. B. Basu, and J. S. Wilson (2010), The future of hydrology: An evolving science for a changing world, Water Resour. Res., 46, W05301, doi :10.1029/2009WR008906.

Yu, B., C. W. Rose, C. C. A. Ciesiolka, and U. Cakurs (2000), The relationship between runoff rate and lag time and the effects of surface treatments at the plot scale, Hydrolog. Sci. J., 45, 709-726.

Zehe, E., H. Elsenbeer, F. Lindenmaier, K. Schulz, and G. Blöschl (2007), Patterns of predictability in hydrological threshold systems, Water Resour. Res., 43, W07434, doi:10.1029/2006WR005589.

Zhang, S., C. Liu, Z. Yao, and L. Guo (2007), Experimental study on lag time for a small watershed, Hydrol. Processes, 21, 1045-1054.

G. Blöschl, J. Parajka, and A. Viglione Institute for Hydraulic and Water Resources Engineering, Vienna University of Technology, Karlsplatz 13/223, A-1040 Vienna, Austria.

L. Gaál, S. Kohnová, and J. Szolgay Department of Land and Water Resources Management, Faculty of Civil Engineering, Slovak University of Technology, Radlinského 11, 81368 Bratislava, Slovakia. (ladislav. gaal@stuba.sk)

R. Merz Department of Catchment Hydrology, Helmholtz Centre for Environmental Research (UFZ), Theodor-Lieser-Str. 4, D-06120 Halle, Germany. 